\title{
13 Water Pricing and Irrigation: A Review of the European Experience
}

\author{
J. Berbel, J. Calatrava and A. Garrido
}

\section{Scope and Objectives}

This chapter reviews the European irrigation sector and its water pricing policies. The first section provides an overview of the irrigation sector in terms of surface water, economic importance and water usage. The second section reviews some of the outstanding issues that have called the attention of the European Union and the Organization for Economic Cooperation and Development (OECD, 1999a,b, 2002) with respect to pricing irrigation water in Europe and OECD countries.

The third section examines the water pricing policies that were in place in EU's various member states and accession countries prior to the promulgation of the Water Framework Directive (WFD). The fourth section offers a detailed description of the WFD, which is by far the most important landmark in the history of the EU's water policy. It has profound implications for the way in which irrigation water will be priced after year 2010. The fifth section studies the existing literature on the likely implications and effects of the application of the WFD in the European irrigation sector while the last section summarizes the main conclusions.

\section{The Irrigation Sector in Europe and Current Trends}

\section{The importance of the European irrigated acreage}

By world standards, Europe is a densely populated continent. Over the centuries, the river systems have been heavily modified to support early industrialization, urbanization and navigation. As a continent, Europe spans the territory from the north of the Artic Circle to the south of Parallel 38. European agriculture uses $44 \%$ of the EU territory and exhibits great variability both along north-south and westeast transects, as a result of geographic and climatic diversity, from the temperate climates of the north to the arid climates around the Mediterranean Sea. The importance of irrigation thus increases from north to south, being an indispensable input for agriculture in most of the arid and semi-arid environments. In Mediterranean countries, irrigated farming accounts for a large share of total water withdrawals (83\% in Greece, $68 \%$ in Spain, $57 \%$ in Italy and $52 \%$ in Portugal), while it represents less than $10 \%$ in Northern European countries. At the same time, there is a wide variety in farming patterns, the crops grown and the contents 
of water laws across the countries of the community. In particular, there are very large differences in average farm size between countries.

As Table 13.1 shows, irrigated acreage represents a significant percentage of the land with annual and perennial crops (FAO, 1997). In addition to the Mediterranean countries of the EU member states (Spain, Italy, France, Cyprus, Greece and Portugal), some of the eastern European countries (Albania, Bulgaria, Romania and the Russian Federation) have large irrigated areas. The irrigated area in the EU has grown from about 6.5 Mha in 1961 to nearly $12 \mathrm{Mha}$ in 1996.

\section{Current problems and trends}

According to the WFD's preamble, the trends in most European countries indicate that the water supplies to the population are threatened by human-induced pressures and that aquatic ecosystems are undergoing severe processes of quality deterioration. As we will see below, reversing these trends is the main objective of the WFD.

National water figures conceal widely diverse situations among European regions. Those suffering from scarcity and deteriorating situations tend to coincide with those in which irrigation is the major water user. Large investments in infrastructure, supply-side policies and disregard for integrated policies have brought water systems in many regions to unsustainable use patterns. Quality and quantity issues are intertwined. Large population densities of generally wealthy populations have encouraged investments to take advantage of climatic patterns across Europe, mostly in tourism and second-home residences and, on the other hand, in agriculture. This demand-driven process, illustrated by the growth of private groundwater irrigation, has also been promoted by the EU Common Agricultural Policy as well as by national governments.

The increase in water abstraction in recent decades has led to a reduction in river flows and a decrease in the level of groundwater, the problem of quantity being aggravated by increasing levels of pollution. Both factors (quantitative and qualitative) involve a loss of good-quality water which is incompatible with the stated environmental objectives of the EU. For instance, in Spain where $28 \%$ of the water abstracted for irrigation is groundwater, there are 51 hydrological units with problems of overexploitation which total $710.7 \mathrm{Mm}^{3} /$ year (MOPTMA-MINER, 1994).

Occasional water shortages with large adverse social and economic consequences, added to water-quality problems all around Europe, ignited a debate, which eventually gave rise to the European policy initiative that materialized in the WFD.

\section{Genesis of the WFD and CAP reforms}

Protection of the environment has been a key theme in recent EU legislation. The Maastricht Treaty (1992) made specific reference to environmental protection, safeguarding human health and achieving sustainable development. This was specifically agreed in Article 130-R:

Community policy on the environment shall aim at a high level of protection taking into account the diversity of situations in the various regions of the Community.

But even before the Treaty was signed, environmental policy objectives were apparent in various types of legal acts.

The development of the European legislation for water resources falls into three 'waves'. The first wave goes back to 1975, and focused on water-quality standards and on the protection of surface water allocated for drinking. The second wave started in 1991 and focused, for the first time, not only on setting acceptable water-quality standards but also on controlling emission levels as a means of achieving the desired standards. The new legislation included the Urban Wastewater Management Directive, the new Drinking Water Quality Directive, 


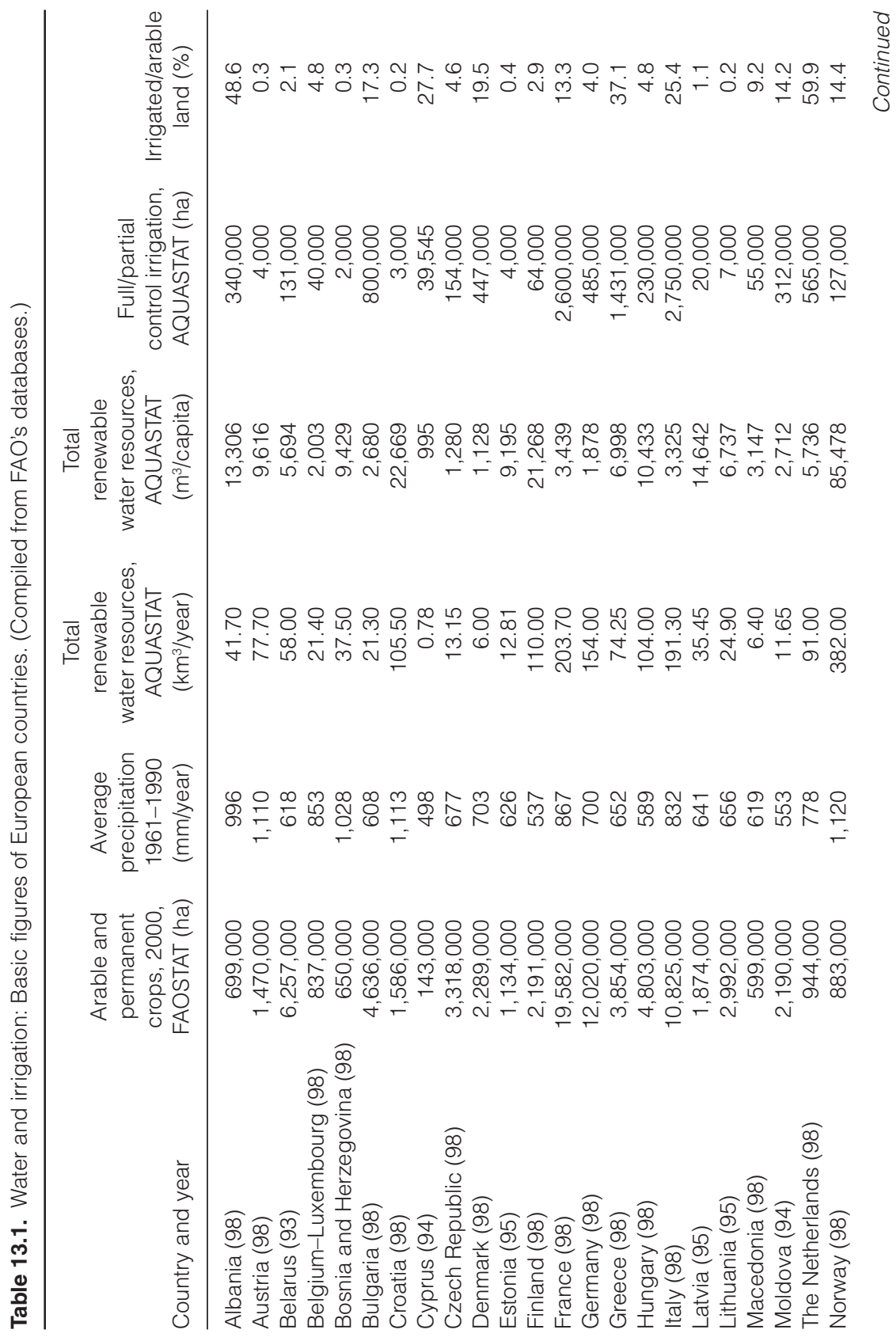




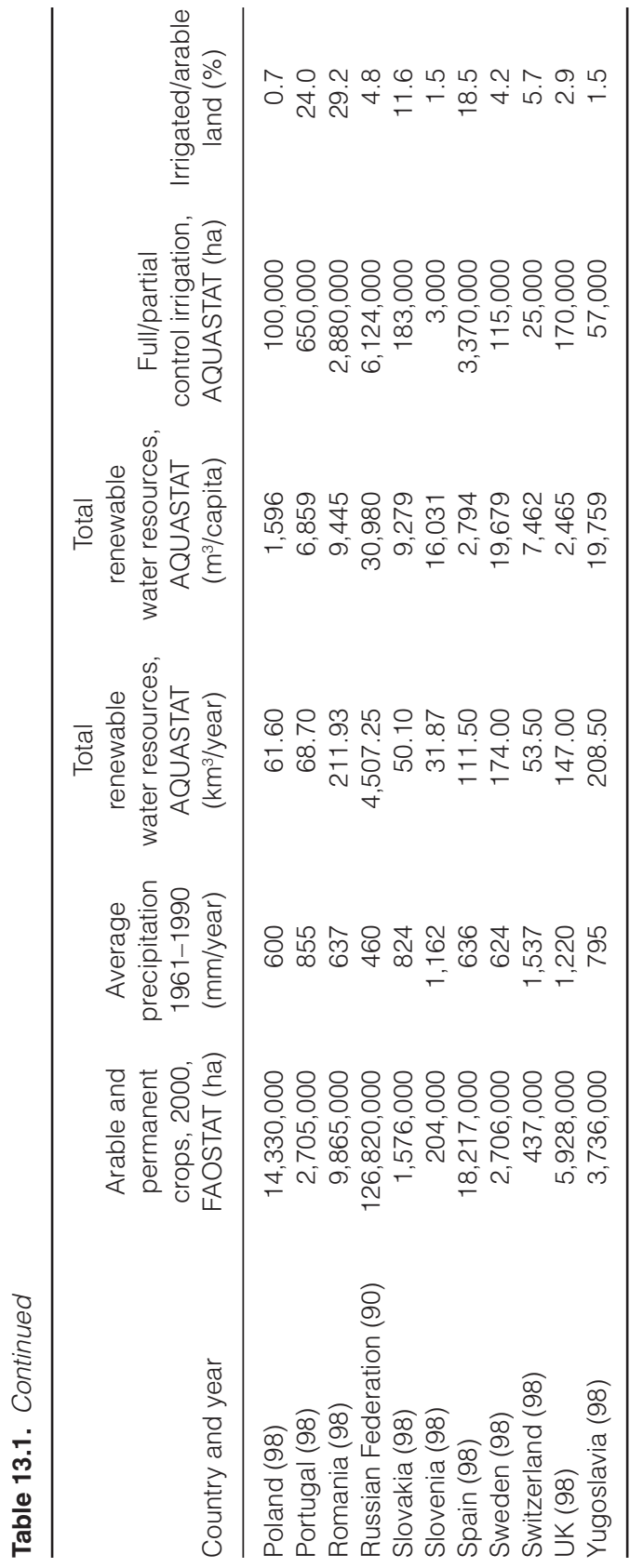


the Nitrates Directive and the Directive for Integrated Pollution and Prevention Control. The third wave addressed water resources in a holistic manner and culminated in the WFD.

OECD (2004) reports that the EU-15 reduced nitrogen use from 69 to $58 \mathrm{~kg} / \mathrm{ha}$ in the decade after 1985-1986, but that the use of pesticides and total agricultural water grew by $5 \%$ and $20 \%$, respectively. This occurred despite the contraction of $4 \%$ of EU-15's agricultural land.

The evidence after 25 years of European legislation was that water resources were still deteriorating, with consequences for ecological systems and human populations. In this context, and given the numerous unresolved problems encountered during the implementation of previous community water directives, the European Council of Ministers asked for a reform of the Water Policy (the 'third wave' of water legislation). The European Parliament and Council adopted the Water Framework Directive in September 2000, which was published in December 2000.

The Directive was subject to a long process of negotiations that was marred by disagreements between the Council of Ministers and the European Parliament that threatened to prevent the Directive from ever being adopted. This controversy can be interpreted as the culmination of conflicting interests between different actors at the local, national and European levels (Kaika, 2003). Ultimately, however, as a result of these complex negotiations, the final text of Directive 60/2000 integrated EU environmental principles (such as the 'polluter pays' principle and a high level of environmental protection that were included in the Maastricht Treaty) within a single document agreed to by all EU members.

The history of the Common Agricultural Policy (CAP) has also been one of adaptation to internal and external forces on the agriculture sector. The internal forces result from the very different positions of the agriculture sectors in member countries, and the changes in those positions over time. Historically, the CAP included heavy subsidies for production as well as for export and import restrictions, and for indirect subsid- ies such as on energy and irrigation costs. Likewise, the solution to rural deprivation was seen to be to support agriculture. There has been a long series of modifications of policy goals and instruments in reaction to changing agricultural policies. An important share of water consumption goes to crops heavily subsidized by CAP (e.g. sugarbeet, cotton and cereals in Spain, Italy and Greece, or maize in France).

On 26 June 2003, EU ministers for agriculture adopted a fundamental reform of the CAP. The reform will completely change the way the EU supports its farm sector. The new CAP will be geared towards decoupled forms of support that farmers will receive irrespective of their production levels. These new 'single farm payments' (that came into force in 2005) are linked to respect for environmental, food safety, animal and plant health, and animal welfare standards, as well as to the requirement to keep all farmland in good agricultural and environmental condition ('cross-compliance'). The effects of this reform on water demand will be important in continental areas (growing non-Mediterranean crops), which are those mostly affected by the change in agricultural support, and less important in areas where fruits and vegetables are the primary irrigated crops.

\section{Issues in Irrigation Water Pricing: Costs and Incentives}

In this section, we discuss some of the most salient issues in water pricing and draw some policy lessons in light of the discussion of experience from individual European countries given in the annex.

\section{Issues related to the definition and measurement of irrigation costs}

\section{Cost recovery}

WFD supports the achievement of economic objectives, specifically cost recovery for water services, including environmental and resource cost within each of the three 
sectors: agriculture, industry, domestic. WFD bases the concept of cost recovery on the concept of 'water services', and the complete meaning of this sentence has been defined in detail in the WATECO guide (2003) that develops the concept of full cost recovery by stating two levels of recovery: 'financial' and 'environmental and resource' costs.

In a perfect competitive market, the prices fall out of the market through the interaction of the buyers and sellers, and the optimum allocation of water is automatically achieved. But with water, and specifically in relation to environmental uses, the prices have to be 'invented'. The problem is to establish a set of prices that results in achieving the optimum allocation of water. As shown in the Annex, the charges for irrigation in the EU countries, as in most other countries, have been inadequate to recover capital and operating costs. Other levels of recovery have been introduced largely in regard to the issue of allocating the water between competing uses, in particular, between human and environmental uses.

The concept of 'water services' is defined in monetary terms as the economic cost of maintaining infrastructures and supplying water. This analysis should be done for the agriculture, industry and domestic urban water sectors. Additionally, on top of these monetary costs, WFD requires the estimation of both environmental and resource costs, and the definition of a programme to recover them. Differences between 'environmental cost' and 'resource cost' are difficult to implement in the real world. It would have probably been more useful to separate 'monetary' (O\&M, depreciation, financial) and 'non-monetary' (environmental and resource) costs.

Resource costs are the most difficult to quantify. Usual notions of resource costs associate them with opportunity costs that are equivalent to the economic value of the opportunities forgone when allocating the resource to a given user. When water markets exist, resource costs can be assimilated to the market price of water netted of the costs incurred when abstracting or moving the water to its final destiny.
The difficulties of separating cost items are related to the different definitions of 'full cost recovery' prices that each country appears to follow. Appropriate policy action should also recognize that an irrigator's water use may entail additional social costs. These social costs may or may not be included in the definition of 'full cost recovery' rates, but it would certainly be in the interests of society to identify them and attempt to reduce them. The following sections clarify these notions and provide cost evaluations found in the literature and recent reports. We will use the following typology for monetary costs: (i) private farmer costs; (ii) irrigation scheme costs; and (iii) public water authority costs.

\section{Private (on-farm) costs}

Private irrigation costs include those items for which the irrigator is entirely responsible, and that farmers generally pay as any other cultivation cost, such as maintenance, energy and labour. There are two main drivers for the increased area under precision irrigation (drip irrigation): the scarcity of water and the scarcity of labour, which make automated irrigation systems very attractive for farmers who face the rising cost of both inputs.

\section{Irrigation district or scheme costs}

Irrigation districts distribute surface water and, less frequently, groundwater to individual farmers, and the costs of running and maintaining infrastructure and associated facilities serving a clearly identified set of irrigators are in principle paid by farmers irrespective of the kind of ownership of the district's infrastructure. In practice, there is abundant evidence of better district cost recovery in private associations than in staterun or publicly owned water infrastructure (OECD, 1999a). Most schemes are managed by irrigation districts, which usually are nonprofit associations with legal status.

In countries such as Italy, Spain, Turkey or Mexico irrigation districts are assigned an instrumental role in water policy implementation and water management. According to the Spanish Water Law, irrigation districts (about 
6200 Comunidades de Regantes are registered, covering $2 \mathrm{Mha}$ ) must have their statutes and by-laws approved by the Basin Agencies and perform a number of key tasks in water management. For instance, they collect farmers' charges and levies charged by the Basin Agency and transfer the revenue to the latter. They have also approved procedures to solve conflicts among irrigators, organize irrigation turns and develop and co-finance rehabilitation projects.

User associations in Spain are mostly collective organizations, irrespective of whether they are served with public concessions (either surface water or groundwater) or from private groundwater rights. The French Associations Syndicales Autorisées (ASAs) have similar characteristics although their size is usually very small, while the Sociétés d'Aménagement Rural (SAR) are purely private organizations. In Italy, water user associations are association of landowners with public status (meaning that they are regulated by law and subject to government supervision); much the same occurs in German 'Wasseverbandae'. In Bulgaria and Romania collective user associations were created in the last decade.

On the other hand, in countries like Austria or Greece water user associations are controlled by public authorities. Lastly, in other countries such as England, Sweden, Ireland or Denmark where irrigation is predominantly an activity of private individual farmers it is not common to find agricultural user associations in charge of managing irrigation (and drainage) schemes. In England, local drainage boards are fairly common, e.g. in the Fens of East Anglia and in the Somerset levels.

Running costs of irrigation districts are borne solely by the irrigators. However, in most countries, investment costs, either in new schemes or in modernization or rehabilitation projects, receive significant subsidies. Most large irrigation infrastructures across OECD countries, irrespective of when they became operative, have been built with public capital grants. New irrigation districts are projected to be developed in the next decade in Spain or Portugal, although in the case of Spain, new irrigation projects are now very limited and targeted to areas undergoing depopulation.

An example of this type of cost is illustrated in Fig. 13.1 that shows the 'internal district cost' (net of Water Agency Tariffs) according to the amount of water supplied, for a selected group of Guadalquivir irrigation districts (surface water). The average internal distribution cost (entirely covered by users) was $€ 0.037 / \mathrm{m}^{3}$ in the Guadalquivir basin in 2003.

The internal costs of an irrigation district may be shared on a volumetric or per-hectare basis, or even defined by a binomial tariff. Table 13.2 reports various irrigation district costs selected from a number of irrigation districts across EU countries.

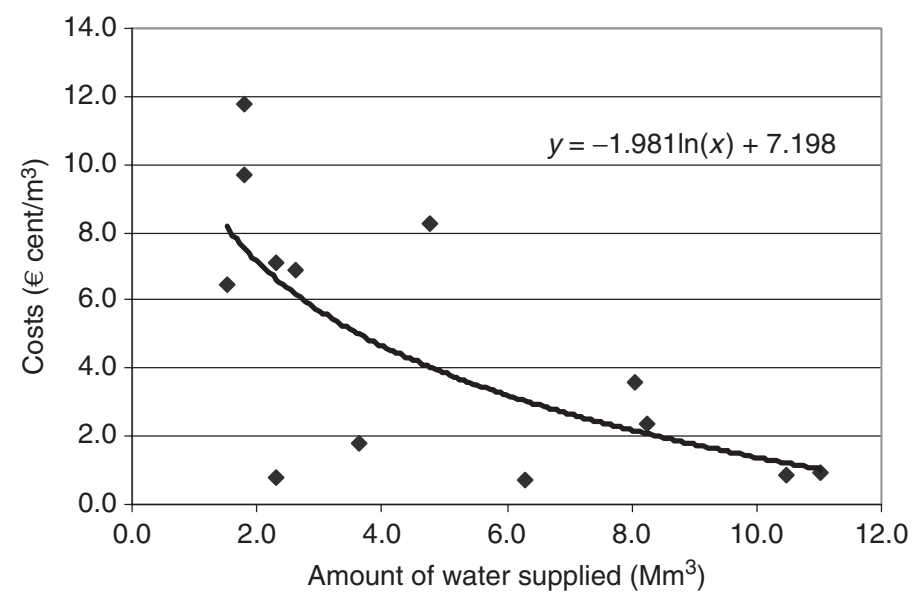

Fig. 13.1. District costs according to the amount of water supplied (Guadalquivir). 


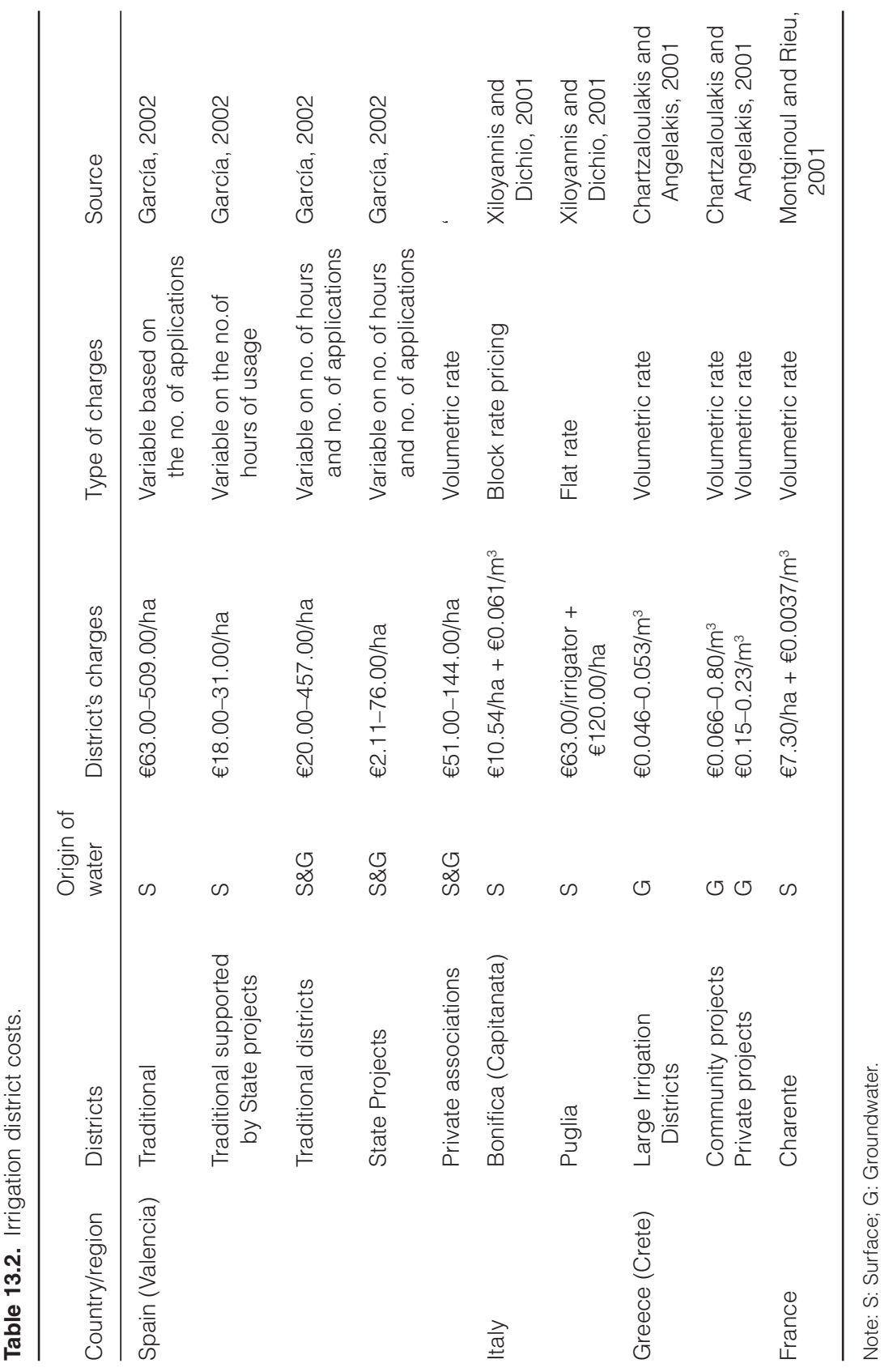




\section{Water authority costs}

A critical methodological issue regarding cost recovery analysis is the definition of the financial costs of Water Authority services. The situation for full cost recovery may vary for each river basin. We illustrate difficulties with this definition with an example from the Guadalquivir basin in Spain, regulated with large dams and infrastructures. The use of historical values in cost recovery is generally accepted in most of the great public infrastructure projects. Specifically for water infrastructure, many dams are older than 50 years and have been theoretically fully paid for by users (farmers and urban users) even when there is a real positive salvage value and they are still in use.

We should remark that the use of 'marginal' or 'replacement cost' is not assumed in the WFD, and we may recall the water privatization in the UK in the 1990s, when the final value of assets was computed neither at 'historical value' (deemed too low a price) nor at 'replacement value' (deemed an excessive price) but estimated based on the 'present value of profit' or, in other words, the ability of buyers to pay. Economic theory defines the capital value of an asset as the present value of the future stream of profit and therefore neither historical value nor replacement value is relevant. In practice, the higher the amount for which the existing assets were sold by the government when the companies were privatized, the higher the charges for water and wastewater required to provide a commercial rate of return on those assets. In contrast, in the case of irrigation, Spain has been given permission by the EU Commission to use historical depreciation criteria for determining the extent of full cost recovery rates.

Generally, difficulties in defining financial costs also arise from how the costs of multi-purpose projects are distributed. In Spain, the sharing of costs between different uses is made by a 'stakeholder agreement' at basin level, considering the following variables:

- Capital cost sharing:

- Flood control: The percentage of costs assumed to provide the pub- lic service of flood control may vary from $20 \%$ (most dams in Spain) to $70 \%$ of some special Mediterranean cases (e.g. Tous dam).

- Urban (domestic and industry) versus irrigation: normally urban users have a different quality of service (daily, seasonal, yearly secured supply) versus irrigation that, in many cases, is residual use.

- Energy (hydroelectric, refrigeration);

- Environmental use.

- Recovery of O\&M: Water agencies are multifunctional as they may not only control abstraction and pollution but, sometimes, also finance infrastructures to supply water. For example, the Guadalquivir Basin Authority recovers $75 \%$ of its O\&M costs for public infrastructures through tariffs, but the remaining $25 \%$ is linked to the cost of environmental services (pollution and flood control, etc.).

Also the computation of financial costs should determine some technical parameters such as: (i) depreciation rate; (ii) salvage value of investment; and (iii) interest rate.

An example of water cost recovery estimation is described by Berbel (2005) who computes costs according to the current Spanish Water Law which states a 'cost recovery formula' defining a water tariff based upon computation of water agencies' O\&M plus depreciation of water infrastructure (the depreciation rate is based upon historical costs without interest rate). When the cost definition and criteria of the Water Law are applied, we arrive at $99 \%$ of financial cost recovery. But when stricter accounting criteria are applied including faster depreciation and $5 \%$ interest rate, financial cost recovery is reduced to $71 \%$. Finally, this percentage may be reduced if we compare the present average tariff in the Guadalquivir river $\left(€ 0.0178 / \mathrm{m}^{3}\right)$ with the 'replacement cost' of $€ 0.06 / \mathrm{m}^{3}$ (full recovery rates for 'La Breña-2 dam' presently under construction).

On the other hand, still in Spain, in the eastern Valencia region, where the use of groundwater is very intense and predominates, 
the final cost of water for farmers ranges between $€ 0.04 / \mathrm{m}^{3}$ and $€ 0.22 / \mathrm{m}^{3}$ for surface water and groundwater, respectively, with an average of $€ 0.115 / \mathrm{m}^{3}$ (Carles et al., 2001a,b; M. García, J. Carles and C. Sanchos, 2004, unpublished data).

To mention another example of cost recovery we may take the last large irrigation project associated with the 'Alqueva dam' (Portugal) with a present price of $1.8 \mathrm{cent} / \mathrm{m}^{3}$ (not covering energy cost) but expected to reach $8 \mathrm{cent} / \mathrm{m}^{3}$ in 2007 if full 'financial cost recovery' is to be achieved. This shows the importance of subsidies as the root of future water imbalances and environmental problems.

Water Authority costs include all cost items directly related to the supply of irrigation water, which are covered by water charges to users and by general taxpayers, with different degrees of cost distribution between the two groups. A common conclusion across countries (see Annex) is that irrigators have been, and still are, heavily subsidized.

\section{Groundwater (on-farm) costs}

Groundwater is the source of water for $20 \%$ to $100 \%$ of European irrigated farms, depending on the region and country. Irrigators using groundwater resources apparently pay all financial costs as they pay investment, maintenance and energy costs for pumping water because they are not supplied by any public scheme. Consequently, in most of the countries, users of groundwater do not pay any tariff to water authorities although some countries (France, the Netherlands, Denmark, the UK) charge a water abstraction fee. We will return to this concept in the next section.

\section{Social and environmental costs}

Non-monetary or social costs caused by irrigation are those inflicted on third parties or on the environment. In both cases, social costs originate from irrigators' use of valuable resources or from their polluting the resource base. The former is generally associated with the opportunity cost, and pro- vides an indication of the value of the water allocated to alternative users. Irrigation can affect the environment through its direct impact upon water resources, soils, biodiversity and landscapes, as well as its secondary impacts that arise from the intensification of agricultural production through the transformation of rain-fed land into irrigated land (European Commission, 2000).

Recent work shows that social costs are far from negligible, and provides a solid basis for urgent policy action. The list of regions or basins where problems related to excessive irrigated water use have been identified would be very long. Generally, resource overdraft is caused by a water demand, both urban and agricultural, quite above the sustainable rate, where the cost paid by users is generally below financial (monetary) recovery cost for surface water and fully or partially paid for groundwater. In south-eastern Spain, where some trading of water occurs especially for fruit, vegetables and greenhouse production, water cost is only around $2 \%$ of total cultivation costs. This implies that water demand will inevitably tend to go beyond sustainable renewable use, indicating that the private cost of water does not reflect the scarcity of the resource.

Regarding pollution by nutrients, the main polluter in Europe is the agriculture sector, including rain-fed and livestock farming. Irrigated agriculture contributes to the increasing nitrate contamination, due to overfertilization. Examples of such direct effects have been found in the Adour-Garonne (France), in several Austrian regions such as the Marchfeld, the Pandofer plateau, and the Welser Heide and Eferding Becken areas, in a number of Spanish regions, mostly located along the Mediterranean coast and main river valleys, and in various nitrate vulnerable Greek zones such as Argolid, Kopas and the Thesaaly plain, where large irrigated areas are located (European Commission, 2000). Nevertheless, in most river basins the impact from livestock and rain-fed agriculture is higher than that from irrigation (e.g. in the Guadalquivir valley nitrate pressure generated by irrigated agriculture is 
around $22 \%$, against $52 \%$ and $22 \%$ generated by rain-fed agriculture and livestock, respectively).

As a consequence of the above-mentioned evidence of irrigation pressure on the environment, countries such as France or the Netherlands try to 'internalize costs' by using an 'ecotax' on water use by irrigators. This ecotax on water abstraction (mostly groundwater) tries to internalize environmental and social costs, but the level of environmental cost recovery is quite low as seen from the first reports presented by the EU member states reporting on WFD implementation. The Spanish government is debating whether to charge an ecotax on all water use (both surface water and groundwater) to contribute to global integrated resource management at the basin level and meet the 2010 deadline set by the WFD for implementation of measures including water pricing. Provisional estimates for this ecotax $\left(€ 1.00 / 1000 \mathrm{~m}^{3}\right)$ make it a 'political contribution of users' rather than an environmental cost recovery charge.

The use of water pricing incentives such as the ecotax is opposed by some authors as Martinez and Albiac (2004) who show that nitrogen pollution is most efficiently abated by targeting either the source or the emissions, and very inefficiently by imposing levies on used water. Nevertheless, most models of irrigation water demand predict a significant reduction when a water tariff is imposed (e.g. $€ 0.06 / \mathrm{m}^{3}$ in Aragon, Spain reduces water demand by $50 \%$ ). This suggests that water and environmental policies must be closely linked and target the most pressing problems, be it water scarcity or nitrogen pollution. Still a further effort of empirical studies is required considering both short- and longterm farmer responses.

Numerous studies have shown that more efficient water use reduces agricultural pollution (Dinar and Letey, 1991; Weinberg et al., 1993; Calatrava and Garrido, 2001). Yet, this does not imply that pollution control should be targeted with water pricing policies. Pollution control can be best performed within irrigation systems by providing precise water applications and monitoring.

\section{Water use incentives}

\section{Incentives for conservation and efficient water use}

According to the neoclassical definition of use externalities, most water problems in the European irrigation sector stem from situations where clear misalignments exist between farmers' private objectives and more general social objectives. The presence of divergences between private and social objectives is manifested by various trends. One is the widening of the divergence between farmers' low water marginal productivity in irrigated commodity production and the sum of the costs incurred by society for making the resources available to them (except for the case of high-value crops). Another is the confirmation that the water costs of competing users may be rising as a result of farmers' water use or polluting practices. Note that the manifestation of adverse incentives is perceived through time and not with snapshots. This implies that policy judgements should be preferably based on whether observed trends show improvements or are worsening.

A list of adverse incentives includes the following:

- Per-hectare water charges: Per-hectare charges (flat rate) are perhaps the most adverse incentive affecting irrigation across OECD countries. Very few irrigated districts relying on surface water have volumetric or other variable rate systems. The wide recognition of the need to change the tariff structures towards volumetric charges has not been accompanied by clear examples of policy implementation. To date, no rigorous evaluation has been made to measure the value of the efficiency losses resulting from the prevalence of flat rates. Montginoul and Rieu (2001) report that irrigators in Charente (France) are charged with two-part tariffs, but the fact that the variable rate is much lower than the marginal benefit of water use in the farms led the managers to impose water quotas in years of scarcity.

The comparison of water use levels of irrigators using surface water with those of 
farmers relying on groundwater may provide an indication of the effects of wrong signalling caused by flat rates. Hernández and Llamas (2001) show that groundwater users tend to use between $25 \%$ and $35 \%$ less than surface users. Yet, groundwater users with pressurized systems will obviously 'use' less than those on old surface water systems. In addition, return flows from upstream surface users may be used downstream, thus increasing the efficacy rates of surface water. All in all, a dollar value of such water use differences is difficult to come by, but may be equivalent to a lower bound of $€ 15.00-35.00 / h a$, with the most conservative assumptions.

As will be argued below, numerous obstacles hinder progress in replacing flat rates with volumetric rates. Among them is the fact that it may not be efficient to do so, under a broad range of realistic situations. Work done by Tsur and Dinar (1997) illustrates how the efficiency gains may not justify the costs of restructuring tariffs. Chakravorty and Roumasset (1991) and Hafi et al. (2001) show that volumetric charges would have wealth redistributional effects in large districts with network losses. Another relevant obstacle is the lack of appropriate water-metering devices in many European irrigation districts.

Investment in irrigation technologies has ambiguous effects in general policy evaluations. Negative effects result from the fact that changes in technology may induce new crop patterns and increase total water consumption. García (2002) shows that drip irrigation technologies have been subsidized in the region of Valencia in Spain but, contrary to general belief, irrigators have not reduced application rates. Similar behaviour has been observed in the Guadalquivir river basin, in the sense that the adoption of drip irrigation has encouraged the planting of new crops (orchards, vegetables, etc.) that are more water-demanding than the preceding ones (Berbel, 2005).

- Inelasticity of demand: The number of studies showing that irrigators' water demand is highly inelastic in the short term, at least at low prices, is at odds with the fact that there are large differences in water consumption and application rates among irrigators and water districts. This means that differences are not governed by prices but by other factors. Response to price increases is not continuous as there is an optimum supply of water for each crop and the water production function implies that the optimum is not sensitive to price increases until a break-even point is surpassed, when a new crop is introduced or farmers simply go for rainfed crops. One would assume that if a set of irrigators seem to operate with low consumption rates, then another operating under similar conditions could be flexible enough to reduce its consumption. Whether it is a change of water price or a reallocation of water rights, the conclusion would be that the latter irrigators can and should reduce their consumption, following a relatively elastic water demand curve.

Before delving into this paradox, García (2002) suggests that water should be thought of as a productive input, whose demand elasticity depends on three factors: (i) the elasticity of substitution of water for other inputs; (ii) the price elasticity of demand for the good being produced; and (iii) the share of irrigators' total costs represented by water costs. The practical application of these principles is that water cannot be substituted by other inputs, except for large-water demanding crops like rice which are grown with little use of capital. Table 13.3 shows some examples in Europe of the relationship between water cost and total cost.

The assumptions embedded in this reasoning turn out to provide clues that may solve the paradox. If technology is fixed, water rights are not tradable and water allotments are fixed by the water authorities in the form of entitlements or quotas, then water demand is likely to be inelastic. Perhaps, looking at water use levels allowing for longterm adjustments, or looking at farms which do not rely on fixed allotments water demand would exhibit larger elasticities.

However, relaxing these three assumptions clears the puzzle, but opens two more. 
Table 13.3. Water cost versus total cost. (From Berbel, 2005.)

\begin{tabular}{lllccc}
\hline Crop/system & Location & River/source & Output $(€ / \mathrm{ha})$ & $\begin{array}{c}\text { Cost } \\
\left(\text { cent/m }{ }^{3}\right)\end{array}$ & $\begin{array}{c}\text { Water/ output } \\
(\%)\end{array}$ \\
\hline Greenhouse & The Netherlands & Underground & 120,000 & 15 & 0.8 \\
Strawberry & Chanza (HU) & Guadiana & 48,193 & 15 & 1.6 \\
Greenhouse & Almeria & Mediterranea & 90,361 & 25 & 1.7 \\
Maize & France & Andaluza & & & \\
Olive & Several & CH Guadalquivir & 6,000 & 10 & 3.3 \\
Cotton & Seville & CH Guadalquivir & 4,000 & 15 & 5.0 \\
Sugarbeet & Palencia & CH Duero & 3,000 & 8 & 12.0 \\
Wheat & Cordoba & CH Guadalquivir & 1,506 & 6 & 12.0 \\
\hline
\end{tabular}

Table 13.4. Water consumption differences among Valencian irrigation districts. (From García, 2002.)

\begin{tabular}{|c|c|c|c|c|c|}
\hline \multirow{2}{*}{\multicolumn{2}{|c|}{$\begin{array}{l}\text { (Type org, type rates) } \\
+, \text { means more consumption } \\
- \text {, means less consumption } \\
\text { S, surface water } \\
\text { G, groundwater }\end{array}$}} & \multicolumn{4}{|c|}{ Type of district rates } \\
\hline & & \multirow{2}{*}{$\begin{array}{c}\begin{array}{c}\text { Two-part } \\
\text { based on } \\
\text { no. of hours }\end{array} \\
(-,-)\end{array}$} & \multirow{2}{*}{$\begin{array}{l}\text { Two-part } \\
\text { based on no. } \\
\text { of applications } \\
(-,+)\end{array}$} & \multirow{2}{*}{$\begin{array}{c}\text { Flat rates } \\
\qquad(-,+)\end{array}$} & \multirow{2}{*}{$\begin{array}{c}\begin{array}{c}\text { Variable } \\
\text { based on no. } \\
\text { of hours }\end{array} \\
(-,-)\end{array}$} \\
\hline $\begin{array}{l}\text { Type of } \\
\text { organization }\end{array}$ & $\begin{array}{l}\text { Traditional districts } \\
\text { supported by state } \\
\text { projects (S) }\end{array}$ & & & & \\
\hline & Traditional districts (S\&G) & $(+,-)$ & $(+,+)$ & $(+,+)$ & $(+,-)$ \\
\hline & State projects (S\&G) & $(+,-)$ & $(+,+)$ & $(+,+)$ & $(+,-)$ \\
\hline & Private associations (G) & $(+,-)$ & $(+,+)$ & $(+,+)$ & $(+,-)$ \\
\hline
\end{tabular}

First, the adoption of water-saving technologies is generally found in districts whose water allotments, granted by basin agencies, have experienced a gradual decline. What is cause and effect is difficult to ascertain, because all that changes, namely, water consumption, allotments and technology adoption evolve simultaneously in response to administered scarcity; and it also shows that administered reallocation based on actual scarcity indeed begets adaptation rather than having to force this through prices at higher costs and to the detriment of equity.

The second one stems from the fact that in virtually all empirical attempts to measure water demand elasticities the districts studied do not face any opportunity cost resulting from their water consumption. This means that most demand analyses posit hypothetical price increases and then infer what would be the farmers' likely response using modelling techniques. Does this imply that water tradability or variable cost charges would suffice in reality to allow irrigators to exploit the efficiency gains found from cross-sectional studies? In other words, is the absence of variable prices responsible for the relatively inelastic demand found by numerous analysts? If the answer is positive, re-forming water charges may result in significant consumption decrease.

Recent work by García (2002), perhaps the most detailed analysis ever done in Spain to explain water use differences across all districts in the Valencia region, shows that water use variability is largely explained by three factors, namely, the type and institutional arrangement of districts, the origin of the used water and the type of pricing scheme. Yet, the analysis is carried out in a very innovative region, where tens of different crops can be grown. Table 13.4 summarizes the econometric results. 
García Mollá's results suggest that traditional districts supported by state projects combined with 'two-part tariff systems' exhibit the lowest consumption levels. They also suggest that all districts using groundwater exclusively or in combination with surface water tend to consume more than those that rely exclusively on surface water resources, indicating perhaps unsustainable use. This result contradicts the conclusions of Hernández and Llamas (2001), and in our view shows that farmers seek maximum economic yields subject to the prevailing market, technological and institutional constraints. Under similar constraints, farmers' consumption will not be driven by the origin of their resources. Lastly, flat rates are directly associated with larger consumption, although causality is not properly established. García Mollá's work provides evidence that seriously disputes the results of Hernández and Llamas (2001), although this work did not consider Valencian districts. Perhaps the conflicting results can be reconciled by the fact that in Valencia surface water is very scarce and much less reliable than groundwater sources, whereas in Aragon or Andalusia surface water is generally abundant. The conflict of surface water versus groundwater is not so evident as there are many cases where surface water is available only $2-3$ months during the year which needs to be supplemented by groundwater to allow for tree cultivation (which may need irrigation when surface water is not available), especially in Andalusia.

Bontemps et al. (2003) show that water demand in southern France is inelastic for low available volumes, and depends crucially on the weather conditions. Rieu (2005) shows that, although demand in Charente is elastic, local authorities have established quotas to avoid the negative effects on farm income. Overall, pricing policies in France seem to be driven primarily by the objective to ensure cost recovery and agence's budget balance, although this is achieved by a great variety of pricing mechanisms (Rieu, 2005).

Dono and Severini (2001) add further evidence from southern Italy to the inelasticity hypothesis, and suggest that water demand turns increasingly inelastic as water charges increase, as the crops that may be able to pay higher prices are mainly high-value vegetables and fruits, which can support high water price increases.

Finally, Massarutto (2003) concludes that the demand inelasticity hypothesis should be framed in relation to the concept of 'exit price'. He claims that the effects on water demand are due to the fact that if water prices are below the exit threshold, they result in demand reductions caused by marginal adaptation of irrigation demand to price variations. Water demand elasticity is always very small, especially once the most obvious water-saving techniques have already been implemented. Above the exit price, water demand is brought to zero because farmers do not cover the input costs and they are better-off not using the water.

- Users reallocation: In a very authoritative essay, Brown (2000) documents the poor records of resource pricing to facilitate reallocation and more efficient use. Water reallocation either occurs because the government mandates it or (generally) because mechanisms are implemented to facilitate voluntary exchanges. At most, multilayered policies, in which new pricing, lower allocations, rehabilitation projects and generous financing are included, can facilitate some trading. In Europe, water markets and liberalization are mostly understood as a process towards giving the private sector more pre-eminence in the areas of urban supply and wastewater treatment. It is only in Spain that there has been a serious attempt to provide for water right exchanges, which required a significant amendment to the water law, but which has so far been used very sparsely.

\section{Other relevant incentives}

- Agricultural policies that promote water consuming crops: Examples of crops, across the EU, with high water requirements supported by CAP programmes were numerous. Maize is con- 
sidered a water demanding crop in temperate countries, and its EU growers were until 2003 entitled to a direct subsidy of $€ 54.00 / \mathrm{t}$ of yield, which usually exceeds $10 \mathrm{t} / \mathrm{h}$. Since the CAP direct subsidies were defined to deliver equivalent levels of income support to all cereal, oilseeds and protein crops, they favour crops such as maize, rice, cotton or tobacco that demand much more water than oilseed crops such as sunflower or colza. With decoupling, this inconsistency has been eliminated, and farmers' use of water will not be driven by subsidy differences across crops.

Between 1973 and 1988, agricultural water use in France grew by $43 \%$, largely due to generous public programmes which provided subsidies to farmers installing irrigation equipment, as well as guaranteeing generally low agricultural water prices. Most of the increase was used in maize production. This trend was reinforced after the 1992 CAP reform replaced production subsidies by per-hectare direct payments, as a result of the higher compensatory payments given to irrigated acreage than to nonirrigated acreage (Dubois de la Sablonière, 1997; Rainelli and Vermersch, 1998).

EU agricultural policy 'Agenda 2000' aimed at supporting a multifunctional, sustainable and competitive agriculture. It was based on the establishment of productionrelated direct aid payments and gave a prominent role to agri-environmental instruments to support farmers' income. In June 2003, the EU decided to replace, from 2006 onwards, most of the direct aid with a single farm payment scheme that is not linked to production. Beneficiaries will be obliged to accomplish certain environmental and food safety requirements.

Work done by Calatrava and Garrido (2001) shows that CAP's Agenda 2000 tended to increase irrigators' water demand in the Spanish region of Andalusia with respect to the pre-2000 situation, which was confirmed in the case of olive oils and vineyards. These authors show that the price support delivered to cotton producers in the region is largely responsible for the large benefit of water in the region. Pressure on water demand by farmers in the region has been on the rise, although recent changes in the Common Market Organization for cotton may have an inverse effect, as cotton support has been largely reduced. Many authors have established a connection between farm subsidies and irrigation water demand in Spain (Sumpsi et al., 1998; Gómez-Limón et al., 2002; Arriaza et al., 2003; E. Iglesias, J.M. Sumpsi and M. Blanco, 2004, unpublished data). Their results show that, indeed, the elimination of farm subsidies has a larger impact on the farmers' welfare than the rise of water prices. When EU farm subsidies become completely decoupled from production in 2012, the economics of irrigation will be more guided by the relative productivity of crops and water accessibility than by relative farm subsidies granted to the crops.

Mejias et al. (2004) add further evidence to the water demand inelasticity hypothesis. In addition, they show that the EU policy based on full decoupling will likely reduce the income losses resulting from WFD's increased water tariffs, at least in Andalusia (Spain).

- Subsidization of irrigation equipment: Positive results come by increasing water productivity, which in turn would reduce the welfare windfall losses resulting from water price increases. Yet, Rainelli and Vermersch (1998) showed that one reason that explains the significant growth in French irrigated acreage was the subsidization of irrigation equipment, which reinforced the CAP incentives mentioned above (as with Spain, cited earlier).

The extent to which subsidization of irrigation equipment should be taken into account in water subsidization analysis is not clear. For one thing, a general belief is that these subsidies are redundant, as irrigators eventually invest in equipment with or without subsidies. Some of the reasons guiding their investment plans are labour cost reductions, lower input application costs through fertigation and upgrading product quality. 
- Inadequate cost recovery rates: Low charges eventually translate into poorly maintained water infrastructures, which in turn reduce irrigators' competitiveness and 'capacity to pay'. Yet adequate cost recovery rates are not sufficient to ensure proper conservation of halfcentury-old irrigation districts. For instance, half of the Spanish irrigated acreage was built before 1960, when farms were small and poorly mechanized, and the country had embarked on reclamation projects. Since 2001, $95 \%$ of the budget devoted to irrigation in Spain is targeted to finance modernization projects, which have reached 1.3 Mha and a budget of $€ 4$ billion (Barbero, 2005). Beneficiary farmers must pay only $50 \%$ of the project's costs, for which they are granted preferential loans. But the process is becoming very costly, as projects have been refocused to include environmental, structural, technological and land planning/tenancy components. The gains are private in the form of more efficient and productive districts, as well as public in the form of water conservation and reduced pollution. By no means would farmers' full cost recovery rates suffice to finance such projects. Yet they are praised and uncontested.

\section{The WFD and Economic Analysis}

The WFD is an environmental norm rather than a general regulation instrument and its main objective is the sustainable use of water through the long-term protection of resources. Article 4 lays down the environmental objectives of the WFD. To avoid possible sources of conflict the WFD explicitly states that it aims to reach a more sustainable use of water resources which can protect or enhance regional development. Also, the WFD establishes derogation or dispensation mechanisms set by Article 4 ensuring that the environmental objectives can be challenged by other socio-economical considerations as long as these are transparent.
Member states will define quality objectives ('good ecological status') but coordination is guaranteed through a calibration exercise to standardize norms for all Europe, producing a benchmarking of water quality and harmonizing the definitions of the good environmental status, in order to avoid different national standards for defining the 'good environmental status'.

With respect to the use of water for irrigation, the WFD mentions a number of important aspects, namely:

- River basin management, whereby water resources are managed at an integrated catchment level (including both surface and underground resources);

- Cost recovery for water services, whereby those who benefit from using water (as a resource or a sink for waste) pay for such services, including the environmental costs, which presently are associated with remediation costs;

- Participation of stakeholders in the planning and decision-making process; - Protection of groundwater and wetlands.

It can be noted that there is very little reference to flood prevention (important to all member states) and drought management (essential to Mediterranean countries). A key concept about water price is that cost recovery refers to water services and not to the water resource itself. Specifically, Article 2, paragraph 38 , defines water services as:

All services which provide, for
households, public institutions or any
economic activity: (a) abstraction,
impoundment, storage, treatment and
distribution of surface water or
groundwater, (b) waste-water collection
and treatment facilities which
subsequently discharge into surface
water.

This definition has an enormous relevance for the correct interpretation of the principle of 'recovery of the costs of the water services' mentioned in WFD Article 9.

Many issues have created barriers to an early agreement on WFD (see Annex: Summary of European Countries' Experiences), but one 
of the most controversial was Article 9 in the first drafts of the proposal. This article originally obliged EU members to charge the full cost of water to users. The final agreement was much vaguer, establishing merely that EU members should try to recover all water service costs, including environmental costs, in accordance with the 'polluter pays' principle.

WFD Article 9 requires member states to take into account the principle of recovery of the costs of water services:

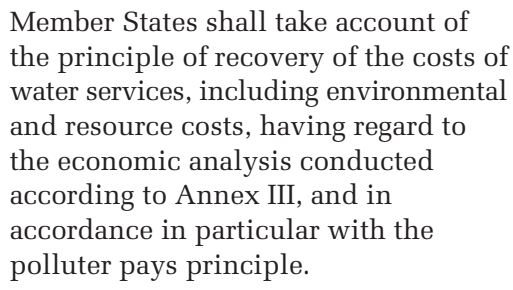

At the same time, Article 5 mentioned in Annex III shows what could be entitled a synthesis of 'Theoretical Economic Analysis of Water Use' for WFD implementation.

Although the economic analysis of water use is an important element of the WFD, precise instructions about the methodology to carry out the economic analysis are not defined in the text. However, in the common strategy for the implementation of WFD, guidance is given by the WATECO reference committee that has developed a guide to illustrate the process of introducing economic analysis and cost recovery into the WFD implementation (Economics and the environment: The implementation challenge of the water framework directive: a guidance document, WATECO, 2003). In addition the European Commission has launched a series of pilot studies to illustrate the application of the WFD in a number of EU basins.

Estimating costs is an important aspect of the economic analysis, and the guide, WATECO (2003), summarizes this aspect as follows:

- Assessing whether the principle of recovery of the costs of water services is met;

- Conducting a cost-effectiveness analysis of alternative policy measures/projects;
- Assessing the costs of alternative management options in the designation of 'heavily modified water body';

- Assessing the need for a derogation based on an economic appraisal of disproportionate costs (such as for the setting of less stringent objectives or a time derogation).

Note that the Directive defines costs as economic costs, which are the costs to society as a whole, as opposed to financial costs, which are the costs to particular economic agents. Catchments may ask for 'derogation' when the application of the WFD has disproportionate costs. However, derogations apply to the environmental goals and not to the application of cost recovery instruments. Finally, WFD considers the use of water pricing as an instrument among many others aimed at the final objective that is 'reaching a good ecological status', and should not be considered as an end in itself. ${ }^{1}$ Nevertheless, there is a general consensus that the application of WFD should contribute to increasing levels of water price for both surface water and groundwater.

\section{The problem with the definition of costs for cost recovery analysis in the WFD}

The main document for this exercise in the WFD is the guide, WATECO (2003). The analysis of financial cost in the WFD has been already explained under the section on 'Water Use Incentives', and first reports done by member states in 2005 show that financial costs are closer to full recovery than expected a priori in most countries, according to the definitions given in the guide.

However, the definition of environmental and resource costs in WATECO is not very precise. Regarding environmental and

${ }^{1}$ More background is provided in COM 477 (European Commission, 2000a) on how water pricing could be used for cost recovery purposes. Many references are made to agricultural water use and to cost components. For further analysis of this concept, readers should refer to WATECO, 2003. 
resource costs, rarely considered in current water tariffs, it is difficult to predict to what extent they will be considered, let alone whether accounting methods and potential increases of tariffs and levies will be defined. The European Commission has been rather conservative in requesting member states to add these costs to the rates. In this sense, it is difficult to predict the extent of positive environmental effects. As an estimation of nonmonetary costs, an ecotax on abstraction is applied in the Netherlands, Switzerland and the UK as an attempt to internalize this cost.

There is lack of information on the environmental cost of water use, and this applies in particular to irrigation. Nevertheless, some European Water Agencies estimate the extra cost (over financial cost value) of the damage to the environment of water use in global terms (urban, industry, agriculture) at $20-25 \%$; the application of economic instruments to agriculture, specifically to irrigated agriculture, should increase the financial pressure on farming.

An additional difficulty for assessing this cost is the pressure-impact evaluation (i.e. local water abstraction impact on global quality of water).

Finally, the methodology for evaluating the resource cost is not already clearly defined in Commission documents, and we believe that this may be included only after financial cost and environmental cost are fully recovered, which is not the case yet. But, apart from being unrealistic, does charging the resource cost make sense when financial cost recovery has not been reached anywhere, either in relation to surface water or groundwater services?

\section{Likely effects of the WFD}

As previously mentioned, the WFD aims to establish a framework for the management and protection of water on the basis of individual river basin districts. In that sense, economic instruments are only one of the possible policy measures to reach the 'good ecological status' that is the final objective of the Directive, including reaching a balance between abstraction and recharge of groundwater, with the aim to achieve water use sustainability. The WFD task force on groundwater will undoubtedly be discussing the definition of safe yields, sustainability and so on. Member states are expected, before 2010, to enforce water pricing policies which give an adequate incentive to improving the efficiency of water use, contributing to the environmental goals of the Directive.

\section{Pricing for financial cost recovery and conservation}

Virtually all analyses of the effects of price increases in irrigation predict that the agriculture sector would be severely hit by the strict application of the WFD, especially smaller and family farms. Studies consider tariff increases between $€ 0.03 / \mathrm{m}^{3}$ and $€ 0.1 / \mathrm{m}^{3}$, which are frequently below full cost recovery rates, and predict reductions in farm income ranging from $10 \%$ to $50 \%$ (Garrido and Calatrava, 2005).

Water pricing will have different impacts depending upon specific characteristics of each farming type. Berbel and Gutierrez (2004) found differences in the water demand curves for three regions in Spain (two) and Italy (one) (see Fig. 13.2 and Table 13.5). The Italian case, which was based on vegetable cultivation, shows a much lower level of water consumption and a much more rigid behaviour of the demand curve due to the high profitability of the crops cultivated. In the Foggia region (southern Italy), where excellent marketing channels for high-valued fruits and vegetables as well as drip technologies exist, there is almost no possibility of water saving. Furthermore, in the Italian case, increasing the price of water would have almost no effect in terms of diminishing water use, and would merely deflate farmers' incomes.

On the other hand, in the Duero valley (northern Spain), where irrigation is mostly based on sugarbeet, the impact of water price rise is that water demand collapses when price is above this crop's productivity and irrigation is abandoned. Climate in this region is very extreme with long and cold winters and hot summers, and irrigation is 


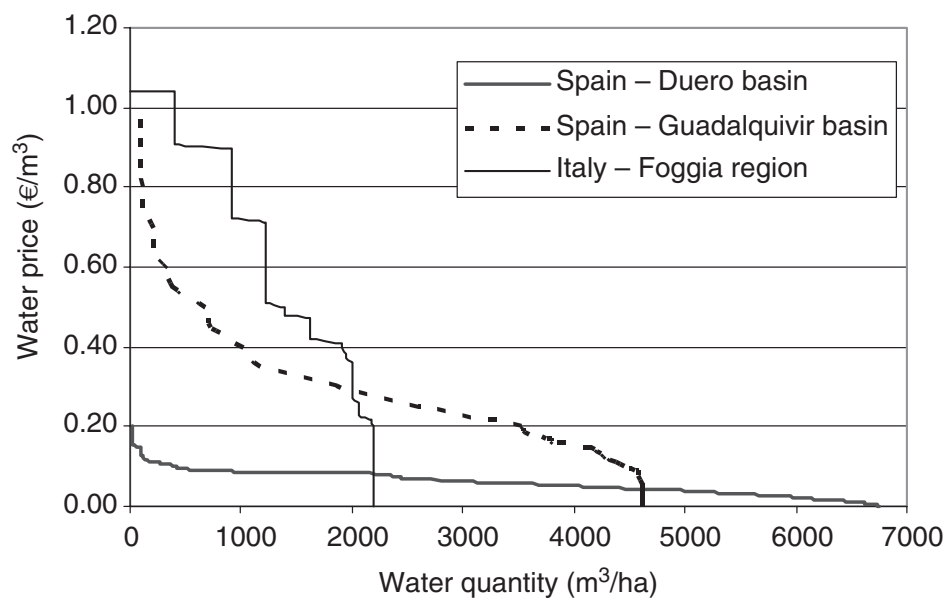

Fig. 13.2. Water consumption according to water price (three regions).

Table 13.5. Water demand characteristics. (From Berbel and Gutierrez, 2005.)

\begin{tabular}{lcc}
\hline Duero (northern Spain) & Guadalquivir (southern Spain) & Foggia (Southeast Italy) \\
\hline $\begin{array}{l}\text { Demand disappears } \\
\text { at } € 0.15 / \mathrm{m}^{3}\end{array}$ & $\begin{array}{c}\text { Demand varies from } € 0 / \mathrm{m}^{3} \\
\text { to } € 1.00 / \mathrm{m}^{3}\end{array}$ & $\begin{array}{c}\text { Demand varies from } \\
€ 0 / \mathrm{cm} \text { to } € 1.00 / \mathrm{m}^{3}\end{array}$ \\
$\begin{array}{ll}\text { Elastic demand } & \text { Inelastic up to } € 0.1 . \text { Then, elastic } \\
\text { Inelastic up to } € 0.23 . \\
\text { High response to water price }\end{array}$ & Low response to water price & Tow response to water price
\end{tabular}

used to grow mainly low-value and heavily subsidized crops. The impact of the new EU single direct payment will likely include a drastic reduction of water demand because of crop shift.

The Guadalquivir case is somewhere in the middle, with some crops dependent on subsidies and others under market competition. In this area, water demand is approaching that of the Foggia case, as an increasing part of demand is already under drip irrigation (olive, citrus and other fruits, $44 \%$ of water consumption and $47 \%$ of area). As drip irrigation is linked to high-value crops (fruits and vegetables), water demand becomes more 'structural' and 'rigid', and the likely effect of water pricing is that the impact will go directly to decrease farmers' income, as significant water saving is already in effect.
These three cases show that the specificity of agricultural systems requires a detailed local analysis. Nevertheless, in general terms, price increase towards full cost recovery may be in the range from $20 \%$ to $400 \%$ over present levels, depending mainly upon two factors: the depreciation criteria adopted in infrastructural cost recovery and the inclusion of all subsidies in order to determine the cost recovery tariff. For less favoured areas, such as the Duero river (Spain), this increase will imply a substantial reduction in area irrigated, farm income and employment. On the other hand, high-value crops (Foggia, Italy) may bear price increases but with the consequence of a transfer of income from farmers to the Water Agency. In any case, the key factor for water saving will be not only the price increase itself but also the use of quantitative controls, so that flat rates (payment by area) 
are changed to volumetric or mixed rates (payment by quantity).

Regarding financial cost recovery and groundwater resources, in many European countries the most profitable agriculture (horticulture, fruit trees and greenhouses) is based on the use of groundwater. In the case of Spain, more than $20 \%$ of farmers, producing more than $50 \%$ of total irrigation value, and located in some of the less waterendowed areas, will be exempt from increases in water charges resulting from the WFD. Most of the irrigation in northern European countries (the UK, Holland) is also based on groundwater, but again water is used for crops with a high marginal value of water, as it increases mainly quality and not quantity (irrigated crops get significantly better prices, see Table 13.4) and water costs are below $1 \%$ of total costs. In other cases, such as France, groundwater is also the main source for irrigation, but in this case most of the water goes to maize (heavily subsidized by CAP). Most likely, the application of the WFD will not result in groundwater prices similar to those applied in surface water schemes.

We may consider that groundwater already recovers $100 \%$ of 'financial private cost', but the WFD implies that this source of water should contribute to environmental and resource costs as we will see in the next section, and before 2010, member states should define their plans to use price instruments, regardless of the source of water.

\section{Other Policy Instruments Related to WFD}

The set of policy instruments related to WFD implementation go beyond water pricing, as irrigated agriculture will also suffer from restrictions in the use of chemical inputs and possible ecotaxes on fertilizers or pesticides. Agriculture and livestock (both irrigated and rain-fed production) are responsible for water pollution by nitrates and phosphorus. Under the 33 priority substances proposed with the implementation of the WFD, heavy metals such as cadmium (linked to phosphorus in agriculture) and about 11 pesticides must be regulated.
Consequently, measures for the adoption of Good Farming Practices will greatly influence irrigated agriculture in the near future. In this sense, we should recall that new irrigation techniques (e.g. drip-irrigated crops) may improve efficiency in the 'product output/fertilizer pressure' ratio as fertilization is in the water directly applied to plant, reducing losses.

Additionally, the future decoupling of farm subsidies, established by Council Regulation $1782 / 2003$, is accompanied by a cross-compliance policy that conditions payments to the farmers achieving 'Good Agricultural and Environmental Conditions' in their parcels, and complying with several European Directives. Five of these relate to the environment, namely the Wild Birds Directive, the Groundwater Directive, the Sewage Sludge Directive, the Nitrates Directive and the Habitats Directive. Crosscompliance policy aims to speed up compliance with several European Directives that were not being adequately implemented by member states.

It is also very important to integrate the implementation of the WFD and the new CAP. First, the more choice farmers have in selecting the crops, the most efficient is water use, and the least income-reduction effects result from water conservation policies (Mejias et al., 2004). Upon the reform of EU agricultural policy, several analyses have explored whether the incentives to use water would change as a result of more decoupled measures of farm income support. It is shown that more decoupled measures of support may make pricing policies more effective and less negative for farmers' benefits. Gómez Limón et al. (2002) show that agricultural and water policies may have conflicting objectives. Yet the trend towards more decoupled measures of support will likely ease the tension which, at least in the EU, has been found in many studies.

Beyond the existing possibilities in the Rural Development Programmes (RDPs), such as agri-environmental schemes, to reduce groundwater consumption or finance technology adoption, there is a need for a further consideration of compulsory water 
use practices in the Codes of Good Practices of the RDP and the cross-compliance scheme. Currently, issues such as restrictions on fertilizers and pesticides are included in these codes, but other issues such as drainage or irrigation technology adoption could also be included.

The costs to farmers derived from the compliance with other environmental EU Directives related to water (see WFD, Article 22) should therefore be added to the costs of complying with the WFD itself, adding further technical and economic constraints.

Indirect effects on agricultural labour are also to be considered. Irrigated agriculture is very important in rural areas of southern Europe and social impacts of water pricing are likely to be high and to raise local opposition. However, these should be compensated by increased demand for labour in other sectors (for instance, the irrigation technologies sector), and some kind of compensation scheme could be established for rural areas that will be seriously affected. A positive effect would be the reduction in the pressure put on public budgets, as expenses collected will increase, investment required for new infrastructures will be reduced and funds will be available for other projects.

\section{Concluding Remarks}

The EU WFD will profoundly change the basis for setting irrigation water pricing policies in the $25 \mathrm{EU}$ member states. The implications of implementing WFD's Article 9 will depend on the evaluation of the costs of the water serviced to agriculture, and the proportion of costs that is eventually imposed on the irrigators' final charges. In most countries, irrigation water charges are lower than the financial cost recovery level and, generally, environmental cost is not considered. Some of the non-EU countries, like Romania, Bulgaria and Croatia, may soon develop similar policies to get ready for accession to the EU.

Most of the water pricing policies are related to surface water under public schemes, but the use of groundwater may account locally for $100 \%$ of irrigation. In the case of groundwater, financial costs of abstraction are fully recovered, but environmental costs are usually not included. But the WFD implies management of all water resources both surface and underground in order to reach 'good ecological status'. Most countries do not consider any form of ecotax for groundwater, or any kind of economic instrument in areas with local aquifers at risk of overexploitation.

Agricultural water tariffs are quite heterogeneous across countries, regions and even within regions. Tariff structures apply almost exclusively to surface water and they rarely reflect relative water scarcity, as they result from complex geographical, technical and institutional factors. Fixed per-hectare tariffs are predominant in southern European countries, mostly in districts supplied with surface water from publicly developed infrastructure, while volumetric charges prevail in northern countries.

The level of cost recovery is very low, and charges are in most cases far below urban or industrial ones. Noteworthy exceptions are the cases of the Netherlands, Sweden and the UK. Some countries (Switzerland and Croatia) have established discharge fees for agriculture, while others, such as Portugal and France, sometimes charge for drainage.

The WFD represents a unique world experience for a number of reasons. First, because it is a decisive step to make farmers responsible for the costs their use imposes on the water system and on the government's budget. Even if 'full cost recovery principles' are loosely applied on irrigation charges, and despite the fact that methods for accounting these costs may not be agreed upon by all member states, the gap between costs and charges will be transparent. Second, member states will need to justify on the grounds of cost and benefit analyses any dispensation to meet the WFD objectives. Thus, member states are accountable to the European Commission for setting full cost recovery rates and for taking into account the 'polluter pays' principle.

Yet, doubts exist on a number of issues before conclusions can be drawn about the effectiveness of this pricing policy. First, the 
EU encompasses widely different irrigation sectors and economies, but policy objectives are inspired on fairly similar tenets. In some Mediterranean regions land planning and rural development are inextricably linked to the irrigation sector. The transition to full cost recovery prices will not be easy in many of these areas. Despite the initial reluctance shown by farm lobbies, many countries, including Spain, have submitted their 2004 economic reports to the EU Commission. The Spanish report, for instance, indicates that the rate of cost recovery in irrigation is slightly below 100\% (Maestu, 2005).

Second, water-quality issues and more efficient allocation are still the most pressing problems in some of the water-stressed regions. If society is in need of more environmentally friendly and more frugal irrigation systems, it may pay to address other factors before squeezing farmers' income with higher charges. This is why many Mediterranean experts have coined the WFD as a 'Northern European' water policy.

Third, despite the above, the WFD will serve as a laboratory experiment conducted on a massive scale and over a large array of conditions. As the EU must set common rules (under the Common Implementation Strategy) they must be written, reported and disseminated to be ready for application in any corner of the EU. On the way to the 2010 deadline for the application of new water prices, the world may benefit from the EU experiences, positive and negative, as well.

Finally, we should consider that WFD is an innovative and ambitious norm as it is the first example of a significant use of economic instruments applied to natural resource management. We cannot quote any other significant example of natural resources (land, soil, etc.) subject to a similar treatment at the scale and socio-economic implications the WFD does.

\section{Annex: Summary of European Countries' Experiences}

In this annex we review the irrigation pricing policies that were in place in a selection of European countries before the WFD was passed in 2000. Table 13.6 attempts to summarize each country's main figures and water pricing schemes.

\section{Belgium}

Less than $5 \%$ of agricultural land in Belgium is irrigated. The agricultural sector in the Flanders region consumes on average $216 \mathrm{Mm}^{3} /$ year of water, out of which $6.5 \%$ goes to agro-industry, $12.4 \%$ to livestock, $8.9 \%$ to greenhouses and $72 \%$ to open-air irrigation (Nys, 1998). Water management and pricing policies in Belgium fall under the responsibility of regional governments.

Agricultural water charges depend on the source of water: users linked to water pipes pay the same as households; users abstracting directly from groundwater sources pay (as from 1998) a levy on declared volumes; and users relying on surface water also pay a levy based on declared quantities.

\section{Bulgaria}

Agriculture consumes $13 \%$ of total water consumption in Bulgaria, that is, $1212 \mathrm{Mm}^{3}$ in 1999 (Kuobratova, 2001). Altogether 582,000 ha ( $65 \%$ of total agricultural area) are equipped for irrigation, although less than $10 \%$ of these are effectively irrigated. Agricultural water management is the responsibility of the Ministry of Agriculture and Forestry, 23 Irrigation Systems Companies (ISC) and 176 Irrigation Water User Associations (IWUAs) (OKO, 2001). Most irrigation water is supplied by the Irrigation Systems Companies, although the importance of collective irrigation is on the rise.

The 1999 Water Act establishes fees for both the use of water and the use of public water facilities, with exemptions for very low consumption and smaller farms. Irrigation water pricing depends on the source of water. Each ISC and IWUA establishes its own price structure. Water prices for IWUAs that manage state infrastructures are set at a lower level than for other agricultural users. IWUAs 


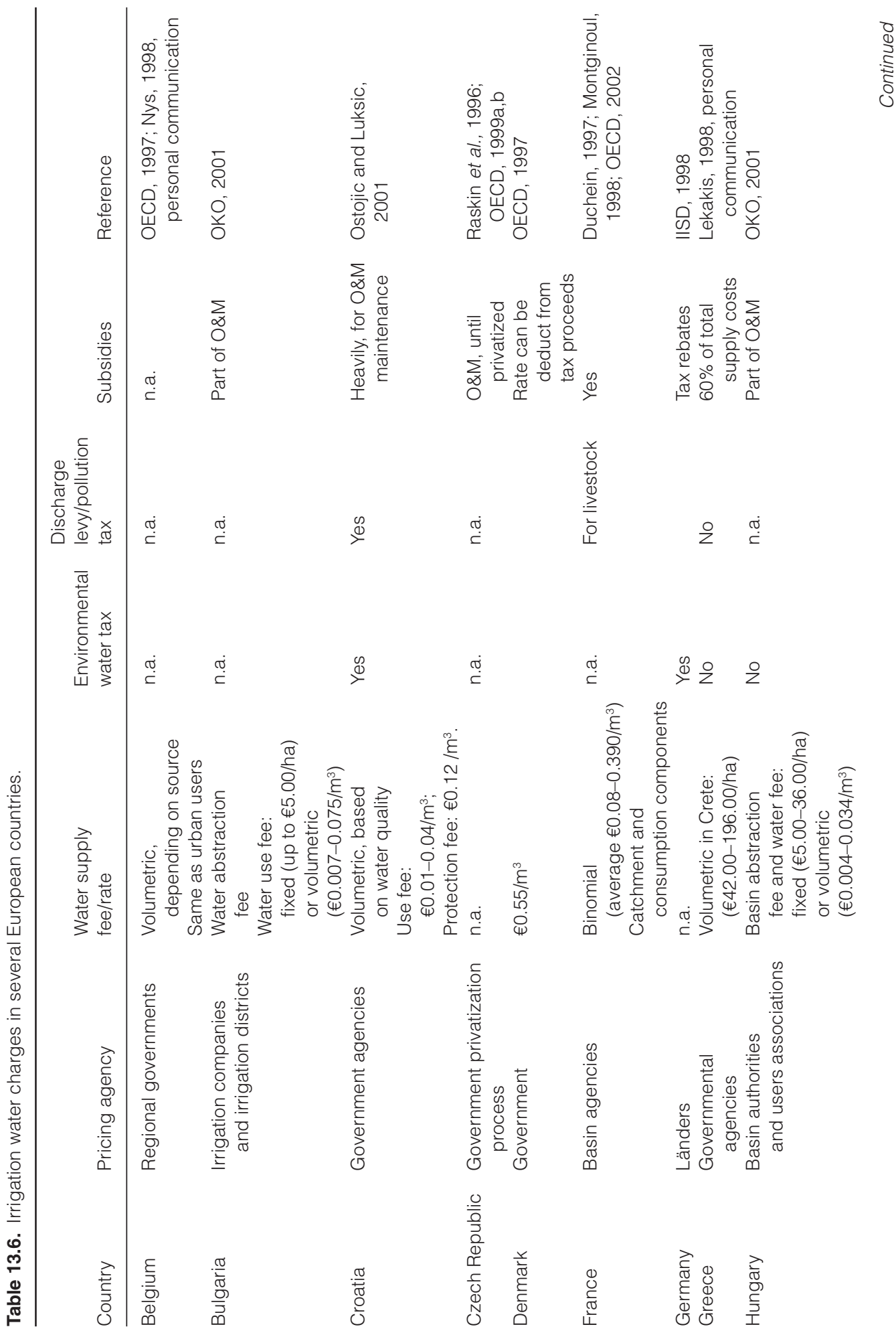




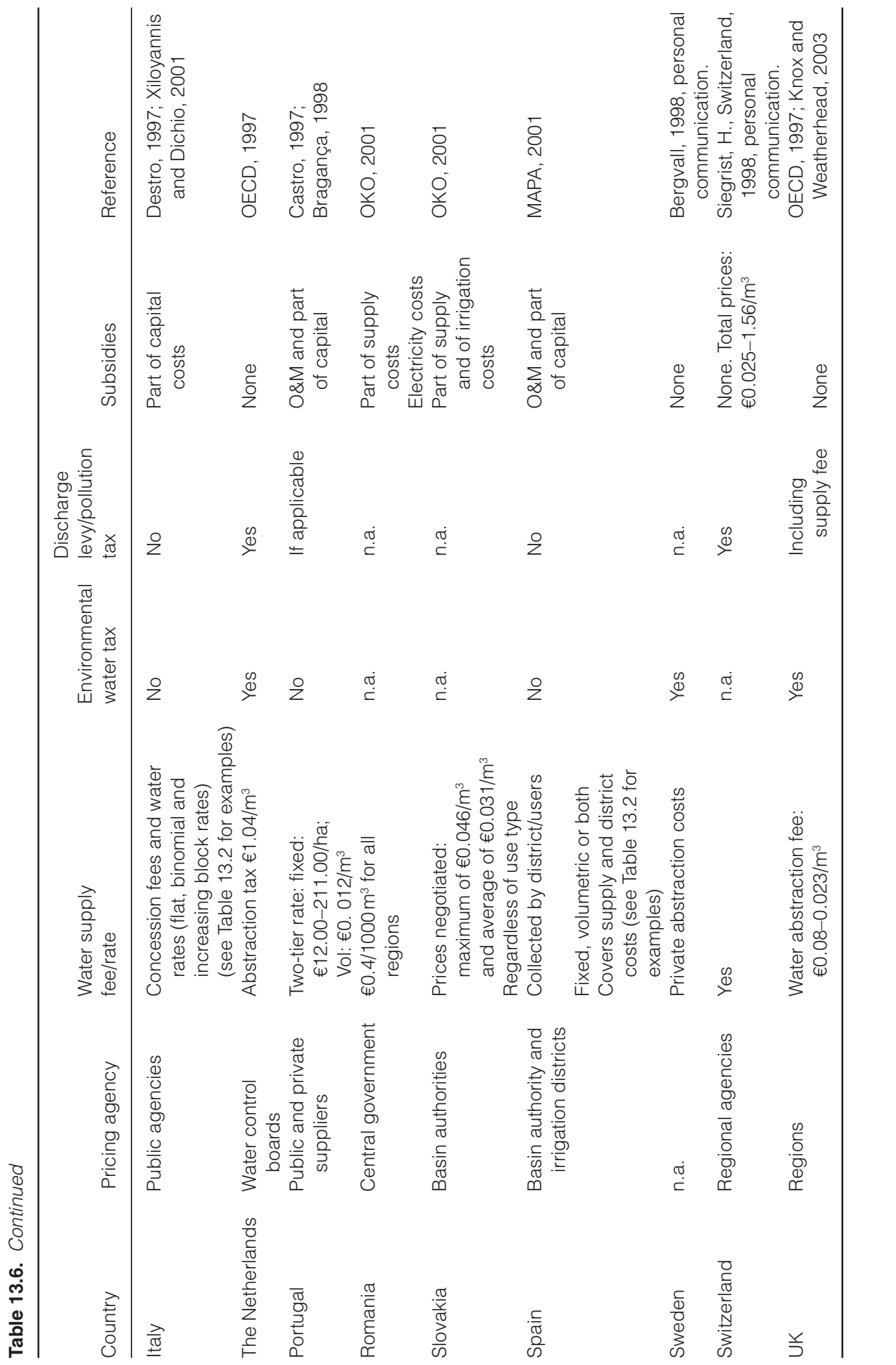


managing their own infrastructures receive no price subsidies (Kuobratova, 2001).

There is a water abstraction fee and a water supply charge. The water supply charge can be either a fixed per-hectare one (up to $€ 5.00 / \mathrm{ha})$ or a volumetric one (€0.007-0.075/ $\mathrm{m}^{3}$ ) or both. Depending on area and water source, irrigation water prices range between $€ 0.01 / \mathrm{m}^{3}$ and $€ 0.09 / \mathrm{m}^{3}$, while the average on farm costs (including irrigation operations) ranges between $€ 0.13 / \mathrm{m}^{3}$ and $€ 0.18 / \mathrm{m}^{3}$. Water tariffs cover part of operation and maintenance (O\&M) costs and, in some cases, part of investment costs (OKO, 2001). Furthermore, the government has subsidized irrigation water prices for both surface water and groundwater in years of scarcity (Kuobratova, 2001).

\section{Denmark}

Irrigated farming in Denmark represents about $35 \%$ of all consumptive uses of water. Farmers using water for irrigation are subject to the 1994 'Green Tax Reform' that imposes a water rate of $€ 0.55 / \mathrm{m}^{3}$ of raw water. However, they are allowed to deduct this tax from their value-added tax proceeds. There is a major concern about pesticide pollution of groundwater and further environmental fees are likely to be imposed on irrigating farmers.

\section{France}

Basin authorities, where most users and stakeholders are represented, can exercise considerable scope in water planning and management and in setting water charges. Water charges in France have two components: a basin component (based on the average volume abstracted) and a consumption component (levied on the difference between abstractions and return flows). The criteria used to set charges vary substantially across basins, and mostly depend on characteristics such as the probability of drought, the type of user, capital costs, ownership and other basin characteristics (Duchein, 1997). Charges cover O\&M and part of capital costs (Chohin et al., 2003).
Farmers pay a binomial tariff, comprising both a fixed per hectare and a volumetric charge. Average water charges for irrigation range between $€ 0.08 / \mathrm{m}^{3}$ and $€ 0.31 / \mathrm{m}^{3}$ (Montginoul, 1997). In areas where perhectare charges are paid, the average tariff is $€ 106.00 /$ ha (Chohin et al., 2003). The ASA and the SAR charge average volumetric tariffs of $€ 0.047-0.054 / \mathrm{m}^{3}$ (Chohin et al., 2003). Some SARs also have optional binomial tariffs (€40.00/ha and $€ 0.07 / \mathrm{m}^{3}$, or $€ 25.00 /$ ha and $\left.€ 0.17 / \mathrm{m}^{3}\right)$. Others, like the SAR in the Languedoc Roussillon region (BRL), have pricing schemes that discourage use above certain thresholds.

In general, water charges across all irrigation units in France have been increasing over time, for three basic reasons. The first is the 1992 Water Code, which sought to broaden the revenue base for water supply companies in order to ensure their financial stability. Second, there has been a large increase in irrigated acreage across France, adding more pressure on several basins during summer or drought periods. Third, pollution is now considered as another 'use' of public waterways and water bodies, so that water authorities can sometimes justify charging 'resource-based' prices which can be added to other accounting and/or capital cost components. Farmers only pay pollution fees for water used in cattle production but not in crop production. Rieu's (2005) comprehensive review of water pricing policies in France shows that policies have been geared towards cost recovery objectives. Yet, there are large capital costs differences across basins and irrigated areas, creating a large range of capital costs recovery, between $15 \%$ and $60 \%$. The pricing systems vary from 'average cost' to 'marginal cost', which are jointly used with systems of quotas.

\section{Germany}

German irrigated agriculture is not very extensive and general water policies tend to override agricultural policies. Water management is the responsibility of the Länders. 
Traditionally, water prices have been based on extraction, treatment and transportation costs. Until several Länders started to establish 'water taxes' in 1988, water remained significantly undervalued with respect to other sectors (IISD, 1998). However, these water taxes deviate from the commonly accepted definition of water charges for two reasons. One is that they are generally levied only in cases where a permit or license is required. Since water metering in the agriculture sector is not common in Germany, the allotted volumes stated in licenses are far below actual abstractions carried out by licensees. The second reason is that the revenues collected from water taxes have often been used to compensate farmers for restrictions on fertilizer use in vulnerable areas. Furthermore, tax rebates (up to $90 \%$ ) exist for those farmers who can provide evidence of being financially impaired by the tax. However, these rebates are conditional upon the implementation of water-saving strategies, and on using surface water instead of groundwater.

\section{Greece}

The relative contribution of agriculture to the GNP of Greece is one of the highest in Europe. Greece has about 1.33 Mha of irrigated land, which represents $38 \%$ of its total arable area and almost $10 \%$ of the country's total land surface. About $20 \%$ of the active population makes its living out of agriculture. Irrigated farming accounts for more than $80 \%$ of the nation's total water consumption. Irrigated acreage has increased by about $65 \%$ in the last 20 years, as a result of a strong political commitment to increase both agricultural production and farm incomes in rural areas. It is also the result of private initiatives, which currently represent about $60 \%$ of the total irrigated acreage, mostly equipped with sprinkler or drip technologies.

The remaining $40 \%$ of the total irrigated acreage $(532,000 \mathrm{ha})$ is composed of cooperative irrigation projects jointly undertaken by the Local Land Improvement Boards (TOEV) and the National Land Improvement General Boards (GOEV). TOEVs manage water allocation, collect farmers' fees and manage collective facilities. GOEVs are semi-governmental organizations that finance works affecting more than one TOEV. Public projects are mainly equipped with modern irrigation technologies, although $41 \%$ of the irrigated area still uses gravity irrigation systems. The construction of irrigation projects comes under the responsibility of rural regional authorities assisting irrigation facilities aimed not only at economic objectives but also at environmental consumption and social objectives as well. Recently, a government-controlled experiment, the Organisation for the Development of Western Crete (OADYK), has begun to operate in Western Crete, providing water for drinking and irrigation purposes. It is a non-profit, self-financed organization.

The Greek water economy is presently approaching 'maturity', and there are few new opportunities to expand irrigation supplies. Irrigation water demand has been slowly increasing in the past decades with a tendency to reach stabilization (Margat, 2002). Public investments in reclamation projects have decreased about $32 \%$ since the 1970s. Although there are some ongoing initiatives which combine environmental objectives with better water and irrigation management, no significant effort has yet been made to make farmers pay for the important rehabilitation and maintenance costs which will be needed in the future. Both the challenging natural conditions of Greece and the relative economic importance of its agriculture sector are factors which explain the delay in implementing water pricing reforms in this sector. Of equal importance is the widely held perception in Greece that water supply projects are multipurpose facilities that contribute towards social progress, environmental conservation and protection.

According to Lekakis (1998), access to water resources has not yet been fully regulated, and the organization of the water management agencies and water suppliers is essentially governed by the civil code. This institutional framework, together with the 
remarkable hydrologic complexity of the country, explains why it is not possible to identify any common trends in Greek agricultural water pricing systems. Another factor which contributes to this heterogeneity is the fact that more than $40 \%$ of agricultural water demand is met by groundwater resources so that water fees are totally dependent on extraction costs, including fuel or electricity consumption. TOEVs set fees to cover administration, maintenance and operation costs of their collective facilities. On average, the revenues collected with these charges represented about $60 \%$ of TOEVs' total expenses in 1994, the rest being covered by the state. Lekakis (1998) also provides an estimated range of pumping costs of $€ 42.00-196.00 /$ ha. Charges paid to TOEVs cover only part of O\&M and nothing of capital costs, while individual irrigators pay both of these (Chohin et al., 2003).

\section{Hungary}

Hungarian agriculture consumes less than $10 \%$ of the total water consumption in the country, of which $92.5 \mathrm{Mm}^{3}$ are used for irrigation, $337 \mathrm{Mm}^{3}$ for fish farming (water supplied to fish ponds) and $125 \mathrm{Mm}^{3}$ for other uses (OKO, 2001, data for 1997). The irrigated area in Hungary was 108,400 ha (1998) although 264,300 ha were equipped for irrigation (4.3\% of total agricultural area).

The 1995 Water Act establishes the need for public licenses for water use. Water management in Hungary depends on three Ministries: the Ministry of Agriculture and Rural Development; the Ministry of the Environment; and the Ministry of Transport and Water, which is responsible for the 12 existing District Water Authorities (OKO, 2001). Farmers in a particular area are grouped in Water Management Associations.

The water supply charge consists of a water abstraction fee (that depends on source type, quality of water and type of use) and a water price. The water abstraction fee is set by the government to finance its water management costs. The water price is freely set regionally by the water supplier.
The water price for irrigation can be a fixed amount per hectare (between $€ 5.00 / \mathrm{ha}$ and $€ 36.00 /$ ha, with higher values in modern districts) or a volumetric tariff (between $€ 0.004 / \mathrm{m}^{3}$ and $€ 0.034 / \mathrm{m}^{3}$ ). Fees account for $20 \%$ of farmers' water-related costs (OKO, 2001) and for $0.5-2 \%$ of the gross value product of crops produced (Strosser, 2003). Water tariffs cover part of O\&M costs. However, in some regions it even covers all capital costs.

\section{Italy}

Irrigated agriculture accounts for $27 \%$ of agricultural land, $30 \%$ of farms and about $50 \%$ of total agricultural production. Around $60 \%$ of Italian agricultural exports are produced by irrigated agriculture (Leone, 1997; Bazzani et al., 2003). Italy has unequally distributed water resources, abundant in the Po valley but scarce and unreliable in the South. Irrigated land is mostly located in the northern Po valley (about $2 \mathrm{Mha}$ ) and in the southern Capitanata region (about 450,000 ha). Farming in Italy represents about $61 \%$ of consumptive use of water, with irrigation estimated at $50 \%$ of withdrawals. Water demand for agriculture has been decreasing since 1970, although future water demand for irrigation is forecasted to stabilize around the present level of consumption (Massarutto, 2001; Margat, 2002).

The Land Reclamation Act (1933) converted all water bodies to the public domain, and set forth the principles which have guided the management of water resources in Italy ever since. The poorly maintained water distribution system in Italy relies mainly on 'Reclamation and Irrigation Boards' (RIBs) (Consorzi di Bonifica e Irrigazione) that are managed by associations of landowners, entities regulated by public law that control land reclamation and water distribution in a certain area. RIBs distribute about $90 \%$ of the water used for irrigation (ANBI, 1992, 1998). Consortia have self-financing capacity to foster rural development, as well as to build irrigation projects. The government provides funds to 
cover all project capital costs, while the Consortia are responsible for managing and maintaining these systems, and collecting charges from farmers.

The average water cost at the farm level is about $€ 36.00 /$ ha, but actual tariffs range from $€ 2.00 /$ ha to $€ 355.00 / \mathrm{ha}$. The tariff system is usually based on the running costs of servicing an area. It is only in a small part of the total irrigated area that water is measured and volumetrically priced. For instance, in the Romagna Occidentale Irrigation Board, 87\% of the total area, served by open canals or nonmetered pipe systems, pays per-hectare charges ( $€ 42.60 /$ ha and $€ 132.20 /$ ha, respectively), while the remaining $17 \%$, equipped with metered, pressurized distribution systems, pay $€ 20.66 /$ ha, plus a volumetric component (Bazzani et al., 2005).

Italian farmers pay much less than other users. Charges cover only part of O\&M costs and nothing of investment or depreciation costs (Chohin et al., 2003). Massarutto (2003) reports a range of $70-100 \%$ O\&M recovery rates in northern Italy and $20-100 \%$ in the South. In Sardinia, rates vary within each Consortia based on the type of water conveyance system, pressure, crops and irrigation technology, ranging from a flat rate of $€ 51.00$ for drip irrigators in Nurra Consortia to $€ 392.00$ for rice growers in Campidano di Oristano Consortia (Aiello et al., 1997). Xiloyannis and Dichio (2001) find large water consumption differences for the same crops between a district in Bassilicata (a flat per-hectare rate) and another in Puglia that uses a block-rate system (a flat rate of $€ 10.00 / \mathrm{ha}$ plus a variable rate of $€ 0.09 / \mathrm{m}^{3}\left(0-1300 \mathrm{~m}^{3} / \mathrm{ha}\right)$, $€ 0.056 / \mathrm{m}^{3} \quad\left(1300-2000 \mathrm{~m}^{3} / \mathrm{ha}\right), \quad € 0.091 / \mathrm{m}^{3}$ $\left(2000-3000 \mathrm{~m}^{3} / \mathrm{ha}\right.$ ) and $€ 0.126 / \mathrm{m}^{3}$ (for any unit exceeding $4000 \mathrm{~m}^{3} / \mathrm{ha}$ ).

\section{The Netherlands}

Irrigation accounts for $60 \%$ of total arable land in the Netherlands. Dutch agriculture uses $149 \mathrm{Mm}^{3}$ of tap water every year $\left(25 \mathrm{Mm}^{3}\right.$ in greenhouses, $38 \mathrm{Mm}^{3}$ in irrigated arable land and horticulture, and $86 \mathrm{Mm}^{3}$ in cattle farming). Water supply is the responsibility of a company wholly owned by the municipalities within its supply area. The water boards or waterschappen have responsibility for land drainage/flood defence and, in some provinces, for water-quality management. They work in close cooperation with the residents/ landowners of their areas, who elect them.

The water boards' costs are fully covered by water users, including farmers who pay the full supply costs and, where appropriate, the full drainage costs as well (National Reference Centre for Agricultura, 1998, unpublished data). The agriculture sector contributes $27 \%$ of the total levies raised for quantitative water management. Unlike in most other countries, the Dutch agriculture sector contributes more revenue to water management costs than it is actually spent in its direct benefit, with a discrepancy of about $5 \%$. The reason is that the main task of water boards is flood protection and land drainage. On average, water supply costs to agriculture amount to $€ 1.04 / \mathrm{m}^{3}$.

Farmers in the Netherlands are subject to a groundwater extraction tax, especially when they draw on tap water resources for cattle production. If they decide to extract groundwater directly themselves, a permit from the Central Government is required if pumping capacity exceeds $10 \mathrm{~m}^{3} / \mathrm{s}$ or if the farmer uses more than $1 \mathrm{Mm}^{3} /$ year, and the farmer has to pay the abstraction tax plus a small provincial tax. Most farmers install small pumping facilities, so they do not have to pay these taxes. Hellegers et al. (2001) conclude that the price of groundwater was inefficient and provided fewer incentives for the adoption of modern irrigation technology than a system that considers the cost of depletion and groundwater contamination in the price of groundwater.

\section{Portugal}

Portugal is relatively well endowed with water resources, although huge differences exist between the North and the South. Irrigated land constitutes about $60 \%$ of the nation's total water supply and $25 \%$ of the agricultural area. 
The Portuguese Water Law combines public and private ownership of water resources. Unlike most countries, the state's role in promoting irrigation projects in Portugal has traditionally been quite limited. Purely public irrigation projects make up only 19$25 \%$ of the 650,000 ha of irrigated land, most of which are located in the southern regions, which make the role of public water pricing policies less important for national-level water management strategy. Traditionally, water abstractions have been allowed free of charge, provided that users do not generate significant levels of pollution. However, major institutional and legal progress has been recently made in terms of implementing water charges for public projects.

Agricultural water tariffs are levied by user associations in accordance with very complex mechanisms and formulae. The complexity arises because WUAs sometimes supply municipal water as well, property size affects the water charges, and charges are combined with drainage fees in projects that require drainage (Castro, 1997). Project beneficiaries are required to pay a yearly set charge called TEC (Taxa de Exploração e Conservação) which includes a selection of no more than three of the following components: (i) a fixed charge per reclaimed or ameliorated hectare of land (ranging from $€ 14.00$ to $€ 211.00$ ); (ii) a fixed charge per irrigated hectare (ranging from $€ 24.00$ to $€ 114.00$ ); (iii) a volumetric charge per cubic metre, if metering is possible (ranging from $€ 0.008 / \mathrm{m}^{3}$ to $€ 0.021 / \mathrm{m}^{3}$ ); (iv) a drainage fee, when drainage of excessive water is required (ranging from $€ 15.00$ to €62.00); and (v) a crop-based fee applicable for specific crops and projects (ranging from $€ 13.00$ to $€ 68.00$ ) (Bragança, 1998).

Although the capital cost charge element has never achieved its intended objective of full cost recovery, the Portuguese system has the peculiarity to compute its payable fees using different interest rates, with the rates varying with soil quality and the crops grown. For instance, Brangança (1998) reports significant water price differences paid by farmers in Sorraia: $€ 0.01 / \mathrm{m}^{3}$ for rice $\left(17,200 \mathrm{~m}^{3} / \mathrm{ha}\right)$ and maize $\left(7200 \mathrm{~m}^{3} / \mathrm{ha}\right)$, and $€ 0.0131 / \mathrm{m}^{3}$ for tomato $\left(5400 \mathrm{~m}^{3} / \mathrm{ha}\right)$. It is clear that the 'ability-to-pay' principle, combined with other agricultural policy objectives, underlies these price differentials. None the less, charges in Sorraia were gradually raised in the period 1991-1997, up to levels that exceed O\&M costs.

\section{Romania}

The total agricultural area in Romania is 14.8Mha, of which 9.8Mha are arable and 3.1 Mha are developed and equipped for irrigation. Of these, only 440,000 ha were irrigated in 1998 because of abandonment and decay of facilities. Romanian agriculture consumes about $10 \%$ of water in the country, of which $284 \mathrm{Mm}^{3}$ are used for irrigation and $664 \mathrm{Mm}^{3}$ for fish farming (OKO, 2001, data for 1997).

The 1996 Romanian Water Law establishes the need for public permits for any water abstraction. The Ministry of Waters, Forests and Environmental Protection is mainly responsible for water management and protection, which are implemented by the 12 basin branches of the National Company 'Apele Romane'. Irrigation user associations have been existing only since 1999. Water prices in Romania are set by the government for each type of water use, so that all farmers in the country pay $€ 0.4 / 1000 \mathrm{~m}^{3}$ of irrigation water used, and the government also covers all electricity costs (OKO, 2001). In those areas where irrigators' associations have developed they have set their own charges to cover their own supply costs.

\section{Spain}

Spain's irrigation practices go back to the times when the Muslims occupied the Iberian Peninsula, starting in the 8th century, and further developed Roman irrigation techniques. This explains why there is so much diversity across regions and even between neighbouring irrigation areas. Irrigation water demand in Spain has been slowly increasing in the past decades and is expected to continue growing with a tendency to level out (Margat, 2002). The era of Spanish modern 
water legislation began in 1985 with the Water Act that replaced the 1879 Water Act. The 1879 Act and the 1911 Irrigation and Land Reclamation Act jointly granted very generous economic conditions to irrigators who benefited from state water projects (Garrido and Calatrava, 2005). Spain’s present charging systems are, in general, far from complying with the WFD. We analysed cost recovery for the Spanish case in the section devoted to the impact of the WFD.

About $70 \%$ of all Spanish irrigated area is serviced by communities of irrigators. In addition to administering the resources and infrastructures they share water among irrigators, and have a major role in water management both at the River Basin Authority (RBA) and district levels. They are active members in the governing and planning boards, and have permanent seats in the Basin Assembly of Users.

Farmers pay a 'regulation levy' and a 'water use tariff' to the RBA through the irrigation district, and an additional tariff to cover the costs of the irrigation district itself (called 'derrama'). Irrigation districts that abstract their water directly and that do not use publicly developed infrastructures only pay the regulation levy plus their own pumping, transport and application costs. A fixed per-hectare tariff is applied in $82 \%$ of the Spanish irrigated area, while volumetric tariffs are applied in $13 \%$ of the irrigated area, mostly in those districts that are served with groundwater and/or that incur energy costs (MAPA, 2001). Binomial tariffs, which combine both a volumetric component, to cover variable costs such as energy or labour, with a fixed per-hectare charge, are applied in 5\% of the irrigated area. Average tariffs paid for irrigation water in areas where water is supplied by RBAs is $€ 0.02 / \mathrm{m}^{3}$, except for the agricultural users served from the TajoSegura Transfer who pay about $€ 0.09 / \mathrm{m}^{3}$, while areas that use groundwater pay an average of $€ 0.04-0.07 / \mathrm{m}^{3}$, based on extraction and other O\&M costs.

\section{United Kingdom}

Irrigation in the UK is all supplementary irrigation. There are 147,895 ha of irrigated land in the UK (Weatherhead and Danert,
2002) growing mainly potatoes and vegetables in the Anglian region (the drier eastern England, 50\%), the Midlands (19\%), Thames $(10 \%)$ and other southern regions $(9 \%)$. In some regions and seasons, irrigation may make up to $80 \%$ of abstractions. There is also some irrigation in Wales, Scotland and northern Ireland.

Although water is becoming increasingly scarce in the east of England, irrigation represents only $3 \%$ of all water diversions. However, water used for irrigation doubled in the period 1975-2000, with an underlying increase in water use for irrigation in the eastern counties of $3 \%$ /year in that period. In response to seasonal water shortages and restrictions on summer abstraction licenses, total water stored in on-farm reservoirs doubled from $33 \mathrm{Mm}^{3}$ to $64 \mathrm{Mm}^{3}$ in the 1984-1995 period (MAFF, 2000). In Scotland and northern Ireland, water resources are abundant, and farmers can take water from adjacent rivers simply by applying for permission, which is granted at no cost.

Irrigation based on river diversion is unsupported. Since the 1960s all abstractions in England require a license. Since 1997, there has been a succession of reviews and policy changes covering all aspects of water management in England and Wales, including the water abstraction licensing system, and the elimination of barriers to the trading of water licenses.

From 1993 onwards, each region is allowed to set charges to recover its water control costs (Rees, 1997). Farmers pay a fee when applying for a water abstraction license, as well as an annual charge that depends on the location, the return flow generated by each irrigation technology, water quality, and the season in which the abstraction is made. Prices vary from $€ 0.008 /$ $\mathrm{m}^{3}$ in Yorkshire to $€ 0.021 / \mathrm{m}^{3}$ in Northumbria. A review of irrigation costs shows that average irrigation costs for large irrigated areas (greater than 50ha) are about $€ 0.43 / \mathrm{m}^{3}$ for direct application in the field, rising to about $€ 0.70 / \mathrm{m}^{3}$ with clay-lined storage reservoirs, and over $€ 0.90 / \mathrm{m}^{3}$ with artificially lined reservoirs. Water costs are less than $7 \%$ of total costs. Thus, at current abstraction charges, summer direct abstraction is always 
cheaper than winter stored water. Summer charges would need to rise to about $€ 0.27 /$ $\mathrm{m}^{3}$ for winter stored water to be a cheaper option. But additional summer water is not available in many situations. The average total costs using trickle systems range between $€ 0.80 / \mathrm{m}^{3}$ and $€ 1.35 / \mathrm{m}^{3}$ (Knox and Weatherhead, 2003).

\section{References}

Aiello, G.M., Cané, G., Fadda, G.A., Murrau, A. and Onanao, V. (1997) Caratteristiche dell' irrigazione colletiva in Sardegna. Revita Irrigazione e Drenaggio 44, 58-63.

ANBI (1992) L'uso Irriguo Delle Acque. Associazione Nazionale Bonifiche Irrigazioni, Roma.

ANBI (Associazione Nazionale Bonifiche Irrigazioni) (1998) La Verità Su Un Territorio Bonificato: I'Italia. Associazione Nazionale Bonifiche e Irrigazioni, Roma.

Arriaza, M., Gómez Limón, J.A. and Ruiz, P. (2003) Evaluación de alternativas de desacoplamiento total de ayudas COP: El caso de la agricultura de regadío del Valle del Guadalquivir. Economía Agraria y Recursos Naturales 6, 129-153.

Barbero, A. (2005) The Spanish national irrigation plan. OECD workshop on agriculture and water: sustainability, markets and policies, 14-18 November, 2005. Adelaide. Oral presentation.

Bazzani, G.M., D’Amore, A., Di Pasquale, S., Fabbri, A., Gallerani, V., Gomez Barbero, M. and Viaggi, D. (2003) La agricoltura de regadìo en Italia y el impacto de la directiva marco de aguas. In: FENACORE (ed.) La Agricultura de Regadío Europea y La Directiva Marco de Aguas. Federación Nacional de Comunidades de Regantes, Madrid, pp. 139-172

Bazzani, G.M., Pasquale, S.D., Gallerani, V., Morganti, S., Raggi, M. and Viaggi, D. (2005) The sustainability of irrigated agricultural systems under the Water Framework Directive: first results. Environmental Modelling \& Software 20(2), 165-175.

Berbel, J. (2005) Análisis económico del agua en la Directiva Marco. Su aplicación a la Cuenca del Guadalquivir. Conferencia ISR, Córdoba, Spain, 28/abril/2005. Available at: http://www.isrcer.org/ jornadas.asp

Berbel, J. and Gutierrez, C. (eds) (2005) Sustainability of European Irrigated Agriculture under Water Framework Directive and Agenda 2000. EUR 21220. Office for Official Publications of the European Communities, Luxembourg, Belgium.

Bontemps, C., Couture, S. and Favard, P. (2003) Estimation de la demande en eau d'irrigation sous incertitude. (Irrigation Water Demand Estimation. With English summary). Economie Rurale July-August 17-24.

Brown, G.M. (2000) Renewable natural resource management and use without markets. Journal of Economic Literature 38, 875-914.

Calatrava, J. and Garrido, A. (2001) Agricultural subsidies, water pricing and farmers' response: implications for water policy and CAP reform. In: Dosi, C. (ed.) Agricultural Use of Groundwater: Towards Integration between Agricultural Policy and Water Resources Management. Kluwer Academic Publishers, Dordrecht, The Netherlands, pp. 241-257.

Camacho, E. (2005) La Eficiencia de las Comunidades de Regantes. FERAGUA-C.H.G (en prensa).

Carles, J., García, M. and Avellá, L. (2001a) Aspectos económicos y sociales de la utilización de las aguas subterráneas en la Comunidad Valenciana. In: Hernández, N. and Llamas, M.R. (eds) La Economía Del Agua Subterránea y Su Gestión Colectiva. Fundación Marcelino Botín and Editorial Mundi-Prensa. Madrid, pp. 153-173

Carles, J., García, M. and Vega, V. (2001b) Gestión colectiva de las aguas subterráneas en la Comunidad Valenciana. In: Hernández, N. and Llamas, M.R. (eds) La Economía Del Agua Subterránea y Su Gestión Colectiva. Fundación Marcelino Botín and Editorial Mundi-Prensa. Madrid, pp. 291-321.

Castro, J. (1997) Portugal. In: Dinar, A. and Subramanian, A. (eds) Water Pricing Experiences. An International Perspective. World Bank Technical Paper 386. World Bank, Washington, DC, pp. 99-103.

Chakravorty, U. and Roumasset, J. (1991) Efficient spatial allocation of irrigation water. American Journal of Agricultural Economics 73, 165-173.

Chartzoulakis, K.S. and Angelakis, A.N. (2001) Water Resources Management in Crete (Greece) with Emphasis in Agricultural Use. Transnational Workshop on Managing Water in Agriculture through Pricing: Research Issues and Lessons Learned. CNR-ISPAIM, Ercolano, Italy, 24-26 May.

Chohin, A., Rieu, T. and Montginoul, M. (2003) Water policy reforms: pricing water, cost recovery, water demand and impact on agriculture. Lessons from the Mediterranean experience. Water pricing seminar, Barcelona, 30 June-2 July. 
Destro, S. (1997) Italy. In: Dinar, A. and Subramanian, A. (eds) Water Pricing Experiences. An International Perspective. World Bank Technical Paper 386. World Bank, Washington, DC, pp. 64-68.

Dinar, A. and Letey, J. (1991) Agricultural water marketing, allocative efficiency and drainage reduction. Journal of Environmental Economics and Management 20, 210-223.

Dono, G. and Severini, S. (2001) The Agenda 2000 CAP Reform and Its Impact on Irrigation Water Use: A Regional Programming Model for a Central Horticultural Area. Transnational Workshop on Managing Water in Agriculture through Pricing: Research Issues and Lessons Learned. CNR-ISPAIM, Ercolano, Italy, 24-26 May.

Dubois De La Sablonière, F. (1997) France: An Incentive Policy for Sustainable Management of Irrigation Water in the Loire-Brittany Basin. OECD Workshop on the Sustainable Management of Water in Agriculture: Issues and Policies. Directorate for Food, Agriculture and Fisheries and Environment Directorate, Athens, 3-6 November.

Duchein, A. (1997) France: Partnership between the Agricultural Community and the Basin Agencies. OECD Workshop on the Sustainable Management of Water in Agriculture: Issues and Policies. Directorate for Food, Agriculture and Fisheries and Environment Directorate, Athens, 3-6 November.

European Commission (2000) Pricing Policies for Enhancing the Sustainability of Water Resources. Communication from the Commission to the Council, the European Parliament, and the Economic and Social Committee (COM (2000) 477 final). European Commission, Brussels.

FAO (Food and Agriculture Organization of the United Nations) (1997) Yearbook. FAO, Rome.

García, M. (2000) Análisis de la influencia de los costes en el consumo de agua en la agricultura valenciana. Caracterización de las entidades asociativas para riego. Tesis doctoral. Departamento de Economía y Ciencias Sociales. Universidad Politécnica de Valencia, Valencia, Spain.

García, M. (2001) Análisis de la influencia de los costes en el consumo de agua en la agricultura valenciana. Caracterización de las entidades asociativas para riego. Tesis doctoral. Departamento de Economía y Ciencias Sociales. Universidad Politécnica de Valencia, Valencia, Spain.

García, M.M., Carles, J. and Sanchís, C. (2004) Caracteristicas institucionales y territoriales y su influencia en el costo del agua como input en la agricultura. VII Congreso Nacional de Medio Ambiente. Madrid (Spain), 22-26 November. Unpublished.

Garrido, A. and Calatrava, J. (2005) Recent and future trends in water charging and water markets. In: Garrido, A. and Llamas, M.R. (eds) Water Policy in Spain. Resources for the Future, Washington, DC.

Gómez-Limón, J.A., Arriaza, M. and Berbel, J. (2002) Conflicting implementation of agricultural and water policies in irrigated areas in the EU. Journal of Agricultural Economics 53(2), 259-281.

Hafi, A., Klijn, N. and Kemp, A. (2001) Efficient pricing and allocation of irrigation water. A model of the Murrumbidgee irrigation area. ABARE Conference Paper 2001. 4, Canberra. Available at www.pc.gov.au/ research/swp/rdia/

Hellegers, P., Zilberman, D. and van lerland, E. (2001) Dynamics of agricultural groundwater extraction. Ecological Economics 37 (2001), 303-311.

Hernández, N. and Llamas, M.R. (eds) (2001) La economía del agua subterránea y su gestión colectiva. Fundación Marcelino Botín y Ediciones Mundi-Prensa, Madrid.

IISD (International Institute for Sustainable Development) (1998) Germany: water taxes. International Institute for Sustainable Development. http://iisd.iisd.ca/greenbud/germany.html.

Kaika, M. (2003) The water framework directive: a new directive for a changing social, political and economic European framework. European Planning Studies 1(3), 299-313.

Knox, J.W. and Weatherhead, E.K. (2003) Trickle Irrigation in England and Wales. Technical Report to Environment Agency. Water Resources R\&D Project W6-070/TR. Environment Agency, Bristol, UK.

Kuobratova, M. (2001) Water, soil and landscape related issues and policies in Bulgaria. Seminar on Sustainable Agriculture in Central and Eastern European Countries: The Environmental Effects of Transition and Needs for Change. 10-16 September. Nitra, Slovakia.

Leone, G. (1997) Stato delle irrigazioni in Italia. Rivista L'Acqua, No. 5.

Maestu, J. (2005) Economic analysis of water use according to Article 5 of the WFD - Main results in Spain. Paper presented at the 6th International Conference of the European Society of Ecological Economics, Lisbon, 14-17 June.

MAFF (Ministry of Agriculture, Fisheries and Food) (2000) Towards Sustainable Agriculture: A Pilot Set of Indicators. Ministry of Agriculture, Fisheries and Food Publication PB 4583. HMSO, London.

MAPA (Ministerio de Agricultura, Pesca y Alimentación) (2001) Plan Nacional de Regadíos. Horizonte 2008. Ministerio de Agricultura, Pesca y Alimentación, Madrid.

Margat, J. (2002) Tendances Contemporaines et Perspectives d'Evolution des Demandes en Eau dans les Pays Méditerranéens, Plan Bleu. Sophia, Antipolis, France. 
Martínez, Y. and Albiac, J. (2004) Agricultural pollution control under Spanish and European environmental policies. Water Resources Research 40(10).

Massarutto, A. (ed.) (2001) Water pricing, the common agricultural policy and irrigation water use. Draft Report for European Commission. Udine, Italy.

Massarutto, A. (2003) Water pricing and irrigation water demand: efficiency vs. sustainability. European Environment 13/2003, 100-119.

Mejias, P., Varela-Ortega, C. and Flichman, G. (2004) Integrating agricultural policies and water policies under water supply and climate uncertainty. Water Resources Research 40(7).

Montginoul, M. (1998) France. In: Dinar, A. and Subramanian, A. (eds) Water Pricing Experiences. An International Perspective. World Bank Technical Paper 386. World Bank (February 1998), Washington, DC, pp. 46-53.

Montiginoul, M. and Rieu, T. (2001) Irrigation water pricing reforms and implementing procedures: experience acquired in Charente and in Morocco. In: Pricing water: economics, environment and society. Conference Proceedings Sintra, 6 and 7 September 1999. European Commission.

MOPTMA-MINER (Ministerio de Obras Publicas, Transporte y Medio Ambiente) (1994) Libro Blanco de las Aguas Subterráneas. Madrid. Pub. Ministerio de Obras Públicas, Transportes y Medio Ambiente.

OECD (1987) Tarification des Services Relatifs à l'Eau. OECD, Paris.

OECD (Organization for the Economic Development and Cooperation) (1997) Water Subsidies and the Environment. OECD/GD(97)220, Paris.

OECD (1999a) Agricultural Water Pricing in OECD Countries. Document ENV/EPOC/GEEI(98)10/Final. OECD, Paris.

OECD (1999b) The Price of Water. Trends in OECD Countries. OECD, Paris, 173 pp.

OECD (2002) Transition to Full-Cost Pricing of Irrigation Water for Agriculture in OECD Countries. Document COM/ENV/EPOC/AGR/CA(2001)62/Final. OECD, Paris.

OECD (2004) Agriculture and the Environment: Lessons Learned from a Decade of OECD Work. OECD, Paris.

OKO (2001) Agricultural Water Management Policies in Bulgaria, Hungary, Romania and Slovakia. Final Report. OKO Consulting, Budapest. http://www.rec.org

Ostojic, Z. and Luksic, M. (2001) Water Pricing in Croatia, Current Practices and Trends. The Regional Environmental Center for Central and Eastern Europe, Zagreb. Available at http://www.rec.org

Rainelli, P. and Vermersch, D. (1998) Irrigation in France: current situation and reasons for its development. Study submitted to OECD Environment Directorate.

Raskin, P.D., Hansen, E. and Margolis, R.M. (1996) Water and sustainability: global patterns and long-range problems. Natural Resources Forum 20(1), 1-17.

Rees, J. (1997) United Kingdom. In: Dinar, A. and Subramanian, A. (eds) Water Pricing Experiences: An International Perspective.. World Bank Technical Paper 386. World Bank, Washington, DC, pp. 139-143.

Rieu, T. (2005) Water Pricing for Agriculture between Cost Recovery and Water Conservation: Where Do We Stand in France? OECD Workshop on Agriculture and Water: Sustainability, Markets and Policies 14-18 November, 2005, Adelaide.

Strosser, P. (2003) Water Pricing in Central Eastern Europe. The Example of Hungary. World Bank Water Pricing Seminar. World Bank, Barcelona, Spain, 30 June-2 July. http://www.worldbank.org/html/fpd/ water/Barcelonameeting.htm.

Sumpsi, J.M., Garrido, A., Blanco, M., Varela, C. and Iglesias, E. (1998) Economía y Política e Gestión del Agua en la Agricultura. MAPA y (ed.) Mundi-Prensa, Madrid, p. 351.

Tsur, Y. and Dinar, A. (1997) The relative efficiency and implementation costs of alternative methods for pricing irrigation water. The World Bank Economic Review 11(2), 243-262.

WATECO (2003) Economics and the Environment. The Implementation Challenge of the Water Framework Directive. Accompanying Documents to the Guidance. European Commission, Brussels.

Weatherhead, E.K. and Danert, K. (2002) Survey of Irrigation of Outdoor Crops in 2001 - England. Cranfield University, Bedford, UK.

Weinberg, M., Kling, C.L. and Wilen, J.E. (1993) Water markets and water quality. American Journal of Agricultural Economics 75, 278-291.

Xiloyannis, C. and Dichio, B. (2001) How to Improve Water Efficiency in Fruit Trees Species in Southern Italy. Transnational Workshop on Managing Water in Agriculture through Pricing: Research Issues and Lessons Learned. CNR-ISPAIM, Ercolano, Italy, 24-26 May. 